\title{
Review Article \\ Spina Bifida: Pathogenesis, Mechanisms, and Genes in Mice and Humans
}

\author{
Siti W. Mohd-Zin, ${ }^{1}$ Ahmed I. Marwan, ${ }^{2}$ Mohamad K. Abou Chaar, ${ }^{3}$ \\ Azlina Ahmad-Annuar, ${ }^{4}$ and Noraishah M. Abdul-Aziz ${ }^{1}$ \\ ${ }^{1}$ Department of Parasitology, Faculty of Medicine, University of Malaya, 50603 Kuala Lumpur, Malaysia \\ ${ }^{2}$ Laboratory for Fetal and Regenerative Biology, Colorado Fetal Care Center, Division of Pediatric Surgery, Children's Hospital Colorado, \\ University of Colorado, Anschutz Medical Campus, 12700 E 17th Ave, Aurora, CO 80045, USA \\ ${ }^{3}$ Training and Technical Division, Islamic Hospital, Abdali, Amman 2414, Jordan \\ ${ }^{4}$ Department of Biomedical Science, Faculty of Medicine, University of Malaya, 50603 Kuala Lumpur, Malaysia
}

Correspondence should be addressed to Noraishah M. Abdul-Aziz; noisha@ummc.edu.my

Received 20 June 2016; Revised 14 November 2016; Accepted 1 December 2016; Published 13 February 2017

Academic Editor: Heinz Hofler

Copyright (C) 2017 Siti W. Mohd-Zin et al. This is an open access article distributed under the Creative Commons Attribution License, which permits unrestricted use, distribution, and reproduction in any medium, provided the original work is properly cited.

\begin{abstract}
Spina bifida is among the phenotypes of the larger condition known as neural tube defects (NTDs). It is the most common central nervous system malformation compatible with life and the second leading cause of birth defects after congenital heart defects. In this review paper, we define spina bifida and discuss the phenotypes seen in humans as described by both surgeons and embryologists in order to compare and ultimately contrast it to the leading animal model, the mouse. Our understanding of spina bifida is currently limited to the observations we make in mouse models, which reflect complete or targeted knockouts of genes, which perturb the whole gene(s) without taking into account the issue of haploinsufficiency, which is most prominent in the human spina bifida condition. We thus conclude that the need to study spina bifida in all its forms, both aperta and occulta, is more indicative of the spina bifida in surviving humans and that the measure of deterioration arising from caudal neural tube defects, more commonly known as spina bifida, must be determined by the level of the lesion both in mouse and in man.
\end{abstract}

\section{Introduction}

Spina bifida is the most common and complex central nervous system malformation in humans. Management of these patients involves various disciplines to ensure the best possible outcome achieved and provide a good quality of life for its patients $[1,2]$. The study of this condition is extremely relevant in that even in the 20 years since the discovery of the benefits of folic acid this condition is highly prevalent around the world and its occurrence does not seem to decrease [3]. Interestingly, the debate is very much ongoing upon the evidence that the United States of America has seen a decline in cases of spina bifida (https://www.cdc.gov/ncbddd/spinabifidadata.html). This review paper intends to compare and contrast spina bifida in humans and spina bifida in the mouse, which is the leading animal model of this devastating condition in light of the information studies on animal models have shed on the human counterpart [4-6].

\section{Spina Bifida in Humans}

Development of the central nervous system including the brain and spinal cord is a complex process beginning with a flat sheet of cells which undergoes sequential thickening, elevation, mediolateral convergence accompanied by rostrocaudal extension, and finally adhesion to form the neural tube (NT) which is the precursor of the brain and the spinal cord. Perturbations of these interconnected processes result in neural tube defects (NTDs), which are the most common congenital malformation affecting this system and are associated with significant complications. NTDs can occur in two major forms: spina bifida (SB) aperta, which 
is the open-lesion NTD, and the closed-lesion NTD, more commonly known as SB occulta.

\section{Epidemiology}

Spina bifida is the most common nonlethal malformation in the spectrum of NTDs and has an incidence generally around 0.5 per 1,000 births, although higher frequencies have been reported [7-11]. In the United Kingdom, the population prevalence of spina bifida is 7.8-8.4 per 10,000 for males and 9.0-9.4 per 10,000 for females [12]. While the prevalence in the United States of America is more than 3 in every 10,000 births $[8,13]$, studies in parts of Asia, such as Malaysia, have also shown a lower occurrence of spina bifida than that of the UK [14]. More recent efforts by our group ("Spina Bifida: A 10-Year Retrospective Study at University of Malaya Medical Centre, Malaysia," manuscript in submission), however, have found that the lower rate of NTDs may not be completely representative as in our hospital alone from the years 2003 to 2012 we have had over 10 cases of neural tube defects per year (spina bifida and anencephaly). Furthermore, certain regions of China have shown much higher preponderance of this condition than in other parts of the world [15-18]. In Africa, for example, spina bifida has been recorded as being low in occurrence in comparison to other birth defects but questions have arisen with regard to record-taking and data management [19]. Gender preponderance differs according to country; in the USA, spina bifida is thought to be more prevalent in girls than in boys $[20,21]$.

\section{Pathogenesis}

Spina bifida aperta (SBA), sometimes referred to as spina bifida cystica, is usually visible at birth as an exposed neural tissue with or without a protruding sac at the site of the lesion. SBA may be referred to as either myeloschisis (Figure 1(a)) or myelomeningocele (Figure 1(b)). Myelomeningocele is when the spinal cord protrudes from the spinal canal into a fluidfilled sac resulting from incomplete closure of the primary neural tube. Myeloschisis is when the incomplete closure of the primary neural plate results in a cleft spinal cord with the edges flush with the defect. The extent and severity of the neurological deficits depend on the location of the lesion along the neuraxis [22].

Meningocele (Figure 1(c)) is often described as a less severe variant of myelomeningocele in which the spinal cord is not found in the sac and is described by embryologists to be absent of neural matter in its herniated sac; and its description is often coupled with that of myelomeningocele which clearly has neural matter herniating at the site of the open lesion. Therefore, the status of meningocele being an open (aperta) or closed (occulta) defect is still debatable in terms of embryogenesis. However, imaging evidence by radiologists has firmly placed meningocele as spina bifida occulta $[3,7,121-123]$.

Myelomeningocele (MMC) is usually associated with a type II Chiari hindbrain malformation, ventriculomegaly, and hydrocephalus $[124,125]$. Chiari type II malformation is the downward displacement of the cerebellar vermis into the cervical vertebral canal $[22,125]$. It is often symptomatic and is diagnosed prenatally with ultrafast fetal magnetic resonance imaging (MRI) [126, 127]. This malformation causes elongation of the brain stem and obliteration of the fourth ventricle, leading to obstruction of cerebrospinal fluid circulation and development of hydrocephalus in $90 \%$ of patients [22]. Treatment of such accompanying hydrocephalus is needed in about $82 \%$ of cases and involves draining of cerebrospinal fluid into either the peritoneal or other body cavity via a subcutaneous shunt [128].

Spina bifida occulta (SBO) is the second major form of NTDs, where the site of the lesion is not left exposed [129, 130]. Spina bifida occulta encompasses lipomyelomeningocele (Figure 1(d)), lipomeningocele (Figure 1(e)), and spinal dorsal dermal sinus tract (Figure 1(f)) ranging phenotypically from (i) dysplastic skin, (ii) tuft of hair, and (iii) vestigial tail as well as other forms of spinal dysraphism, which lack a pathogenic representation when the vertebrae develop abnormally leading to absence of the neural arches $[131,132]$. In symptomatic cases, tethering of the spinal cord within the vertebral canal can result in pain, weakness, and incontinence in otherwise normal, healthy children or adults [133].

\section{Treatment and Management}

Management of patients with myelomeningocele has improved drastically from the mid-1970s when patients were sometimes denied treatment based on the severity of their condition [134] to the current state-of-the-art prenatal in utero repairs performed at highly specialized centers $[127,128]$. Neonatal surgical closure of the lesion is considered the standard of care against which all novel management options are compared [22, 135, 136].

NTDs have a profound impact on society. The morbidity and mortality rates of spina bifida patients decrease with improving medical care. Taking the United Kingdom as an example, Bowman et al. [137] in their 25-year follow-up of 71 spina bifida aperta patients found that at least $75 \%$ of these children can be expected to reach their early adult years [137]. Moreover, as many as $85 \%$ are attending or have graduated from high school and/or college. More than $80 \%$ of young adults with spina bifida have social bladder continence. In the same study, $49 \%$ had scoliosis, with $43 \%$ eventually requiring a spinal fusion. Approximately one-third of patients were allergic to latex, with six patients having experienced a lifethreatening reaction. Renal failure was 6.8-9.0 times more common for males and 9.2-11.5 times more common for female patients compared with the general population in each of the years 1994-1997 in the UK [138]. Therefore, longer life equates with the need for progressively better quality of life.

The sequelae of NTDs are staggering and appear to have not only anatomical effects secondary to the primary defect but also functional, emotional, and psychological morbidities including bladder and bowel incontinence, paralysis, musculoskeletal deformity, and shunt malfunctions and infections, among others. Moreover, the costs involved in maintenance of spina bifida patients include mobility aids (orthoses, wheelchairs, and crutches), medications, and the cost associated with shunt revisions, in addition to the cost 


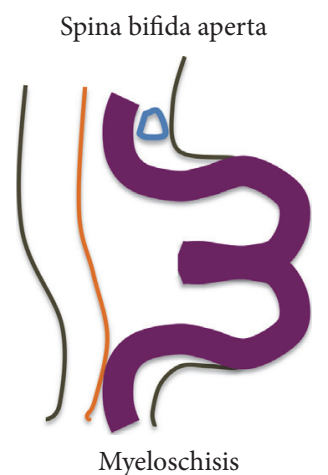

(a)

Spina bifida aperta/spina bifida occulta

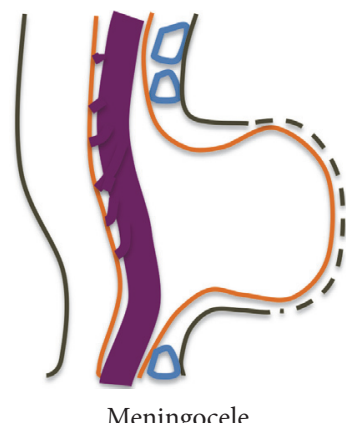

(c)

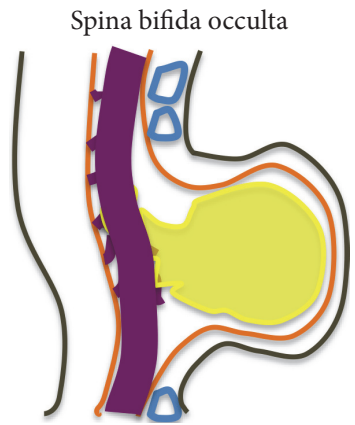

Lipomeningocele

(e)

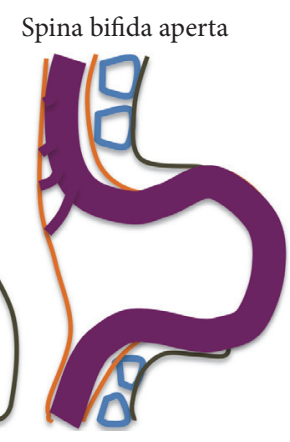

Myelomeningocele

(b)

Spina bifida occulta

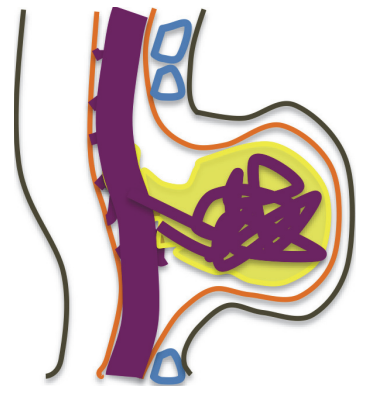

Lipomyelomeningocele

(d)

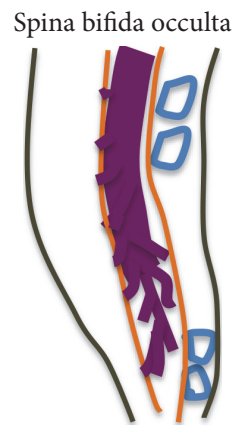

Spinal dorsal

Dermal sinus tract

(f)

Figure 1: Schematic representation of the open (aperta) and close (occulta) types of spina bifida. (a) Myeloschisis which represents the most severe form of open spina bifida. (b) Myelomeningocele which represents another typical severe form of open spina bifida (spina bifida aperta/spina bifida cystica). The typical representation is that of the spinal cord lying outside the spinal canal. (c) Meningocele that represents open or close spina bifida (the skin may or may not be present) but spinal cord does not lie outside the spinal canal. (d) Lipomyelomeningocele that represents closed spina bifida (spina bifida occulta) (covered with skin) but spinal cord is intermeshed with lipid globules (in yellow). (e) Lipomeningocele that exhibits closed spina bifida but spinal cord does not lie outside spinal canal even though lipid globules are present. (f) Spinal dorsal dermal sinus tract; spina bifida occulta with vertebral arches missing (often asymptomatic and is thought to be a mesodermal defect and a defect of secondary neurulation).

of modifications to public utilities that are required to enable disabled access. Ultimately, its compound nature results in an immense financial burden amounting to $\$ 1,400,000$ per child affected by NTD over a 20-year life span [139-142].

5.1. Syndromic and Nonsyndromic (Isolated) Spina Bifida. A small proportion of NTDs in live born infants are associated with specific syndromes that are associated with chromosomal or single-gene disorders [143]. NTDs are currently considered as "complex" disorders with genetic and environmental factors playing roles in causation [144], which have been summarized in Table 1. Craniorachischisis and encephalocoele have the highest rate of syndromic association, anencephaly and high spina bifida have intermediate 


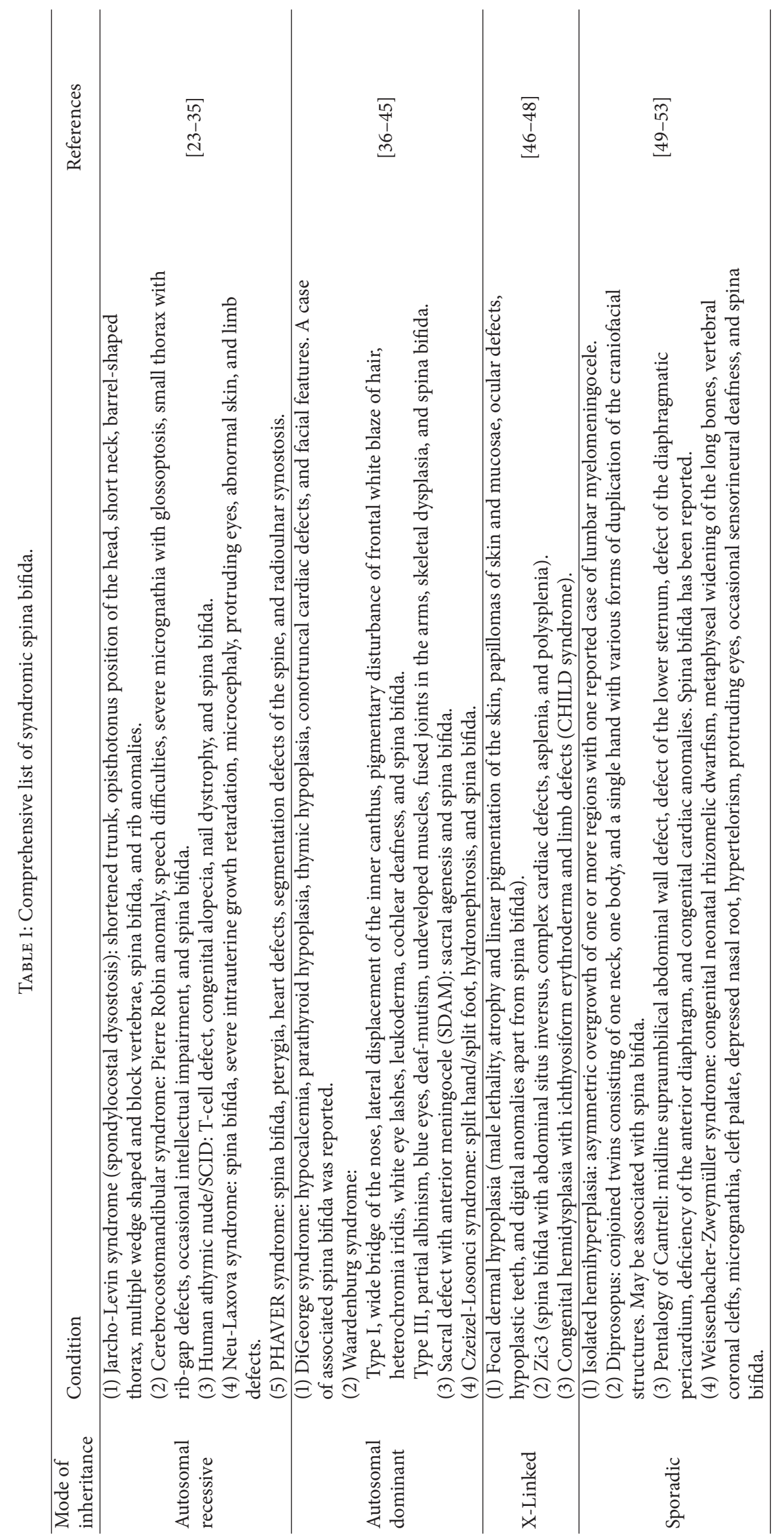


rates, and caudal spina bifida has the lowest rate [145]. The role of folic acid in preventing syndromic NTDs turned out to be not as gratifying as for nonsyndromic (isolated), multifactorial NTDs [146]. It should be noted that while syndromic NTDs may have identifiable genetic causes, many of the nonsyndromic (isolated) NTDs have unidentified genetic etiology. Most of human neural tube defects are nonsyndromic with NTD being the only defect. The focus of this review paper is on nonsyndromic (isolated) spina bifida apart from the clearly stated syndromic spina bifida mentioned specifically in Table 1 .

5.2. Causative Factors, Detection, and Prevention of Spina Bifida. The etiology of spina bifida is heterogeneous [147150]. Most nonsyndromic spina bifida is thought to be of multifactorial origin [151] with influence of both genetic and environmental factors $[144,152]$. Among the environmental factors associated with increased risk of spina bifida are increased pregnancy weight [153-158], maternal smoking [159-161], drug intake specifically of antiepileptic drugs [162$164]$, and maternal illnesses such as diabetes $[165,166]$ and hyperthermia [167]. Dietary factors including water chlorination [168-170], inositol intake [171], simple sugar intake [172], and the intake of trace elements and other micronutrients [173-176] have been proposed to act as either contributory or preventive factors for spina bifida. Isolated spina bifida is caused by cytogenetic abnormalities in $2-16 \%$ of cases [177179].

Elevated levels of maternal serum alpha-fetoprotein are usually indicative of spina bifida aperta $[180,181]$ but can be associated with other conditions (e.g., twin gestation and abnormalities of placentation including placental lakes and placenta previa) and ultrasound is needed to confirm the diagnosis. Screening obstetrical ultrasonography is the initial routine method for the detection of NTDs during pregnancy in many countries. However, it sometimes fails to detect closed spina bifida $[182,183]$. In highly specialized fetal centers, use of ultrafast fetal MRI has enabled detailed anatomical evaluation of the defect and accurate assessment of its accompanying effects [126].

It has been over 15 years since the Medical Research Council Vitamin Trial involving 33 centers around the world conclusively showed that $72 \%$ of recurrent NTD cases could be prevented by folic acid supplements in the periconceptional period [184]. A further study [185] showed that the first occurrence of spina bifida could also be prevented by folic acid. However, not all NTDs are responsive to folic acid and inositol has been shown as a possible additional therapy, based on prevention of spina bifida in folate-resistant NTDs in mice as well as the PONTI human trial $[186,187]$. Calcium formate too has been shown to have preventive effects on NTD in mice but evidence is not yet forthcoming in prevention of human NTDs [188-190]. There still remains room to study whether there are other supplements out there that can prevent spina bifida.

\section{Surgical Management of Spina Bifida}

Surgical management of spina bifida here is discussed as a 2-point discussion: first is surgical management prior to the advent of in utero repair of open spina bifida and second is in utero repair leading to the Management of Myelomeningocele Study (MOMS) trial [128]. Postnatal repair of open spina bifida repair is a requirement in order to prevent further mechanical damage and infection. The lesion either may be closed primarily with the aid of skin and muscle flaps or may require a synthetic patch such as AlloDerm (LifeCell Corp., Branchburg, NJ) [191], gelatin, or collagen hybrid sponges [192]. In utero MMC repair in humans was first reported in the landmark paper published in 1998 [127]. However, since then, a handful of centers have been offering in utero repair. Furthermore, its popularity has increased in Europe [193]. The principle of in utero repair is to prevent the 2hit hypothesis much described in previous literature that the child is exposed to neurological deterioration contributed first by failure of the neural tube to form and secondly by physical and chemical perturbation inflicted on the exposed neurological tissue of the open lesion $[128,194]$. In an elegant experimental study, Meuli et al. [195] concluded that surgical exposure of the normal spinal cord to the amniotic space in a 75-day sheep fetus results in a MMC-type pathology at birth with clinical, histological, and morphological attributes comparable to human MMC. Heffez et al. [196] has demonstrated that spinal cord injury caused by exposure to the intrauterine milieu can be prevented by primary closure of the fetal skin incision as late as hours after creating the defect. It also demonstrated that ongoing exposure beyond 24 hours leads to spinal cord damage and permanent neurological deficit. Moreover, animal studies have previously shown that prenatal coverage of a spina bifida-like lesion preserves neurologic function and improves hindbrain herniation $[195,197,198]$.

The first human prenatal repair of MMC was reported in Tulipan et al. [199]. Cumulative data suggested not only a dramatic improvement in hindbrain herniation but also increased maternal and neonatal risks including preterm labor, uterine dehiscence, and increased risk of fetal and neonatal death among others. Adzick et al. [128] investigated the effects of prenatal repair of $\mathrm{MMC}$ via a randomized prospective study. It reported that prenatal surgery for MMC performed before 26 weeks of gestation decreased the risk of death or need for shunting by the age of 12 months and also improved scores on a composite measure of mental and motor function, with adjustment for lesion level, at 30 months of age. Prenatal surgery also improves the degree of hindbrain herniation associated with Chiari II malformation, motor function, and the likelihood of being able to walk independently, as compared with postnatal surgery [128]. Open prenatal repair comes with an increased maternal and neonatal risk including preterm labor, uterine dehiscence, premature rupture of membranes, and increased risk of fetal and neonatal death. The main goal for prenatal repair of $\mathrm{MMC}$ is to achieve skin closure to prevent further damage of the placode and arrest the CSF leak.

\section{Human Spina Bifida Genes}

Despite the 250 mouse mutants with NTDs to date, there has yet to be a significant breakthrough for human NTD gene(s) both causal and/or associated with NTDs that can be used for 
genetic screening worldwide $[4,7]$. The importance of finding candidate gene(s) as a genetic screening tool for potential parents cannot be undervalued as it has been estimated that the total lifetime costs for patients with spina bifida (spinal NTDs) amount to about $\$ 1.4$ million in the US and more than $€ 500 \mathrm{k}$ in Europe, with $37.1 \%$ of the total cost attributed to direct medical costs and the remainder in indirect costs, including the needs of the caregiver [200].

Despite observation of multiplex nonsyndromic NTD cases in multigenerational NTD families as seen in 17 US and 14 Dutch families with more than 1 NTD-affected person, there are other NTD cases that are simplex and sporadic as seen in identical twins with lumbosacral lipomyelomeningocele with no known familiar history of NTDs [201, 202]. This suggests that NTDs have a multifactorial genetic etiology.

To date, the strongest candidate thus far for a potential NTD screening gene is the methylenetetrahydrofolate reductase (MTHFR) C677T (rs1801133) polymorphism in populations of non-Latin origin (meta-analysis study) [203]. In recent meta-analysis study, Zhang et al. support the significant association between C677T and NTDs in casecontrol studies (22 studies, 2,602 cases, and 4,070 controls) [204]. The second most studied MTHFR variant is A1298C, which did not report any significant increase in risk of NTDs [204]. Another meta-analysis study by Blom et al. (2006) reported increased risk in mothers and associated with NTD infants who are homozygous for C677T variant [205]. In spina bifida case studies, MTHFR C677T variant was clearly reported as associated gene or risk factors in Irish (451 spina bifida patients), mixed USA, mixed UK, and Italian cohort but not in other 180 Dutch patients (Table 3), while A1298C variant was reported with no association to spina bifida cases in Italian, Mexican (Yucatan), and Dutch population (Table 3). MTHFR is the most studied human spina bifida gene, as its role in folate one-carbon metabolism fits into a clear mechanism of NTD. However, the studies have not been well replicated in many other populations across the world, indicating that it is not likely to be either a major contributor or a common factor in NTD globally.

Other genes such as the planar cell polarity (PCP) genes, which have been studied in spina bifida cohorts among Italians, Americans, and the French, are VANGL1 and CESLR1 [44, 82-84]. The noncore PCP gene SCRIB has also been implicated as a spina bifida gene among the American cohort [85]. However, noncore PCP gene association needs to be explored further in larger NTD cohorts. To date, over 100 human spina bifida genes have been used to screen for spina bifida with 48 genes reported as a potential risk factor as listed in Table 3 which was reviewed in Greene et al. [93]; further candidates since then are NKX2-8, PTCH1, Glypican5, PARD3, Paraoxonase 1, COMT, AMT, and GLDC genes [16, 17, 206-211]. All of these do not represent a potential global spina bifida gene. Therefore, a strong candidate spina bifida gene(s) for the world population has yet to be discovered.

\section{Spina Bifida in Mouse}

There exist more than 250 mouse models with neural tube defects, of which 74 are of spina bifida (Table 2) [4], yet there does not exist a single mouse gene which can be used to screen the orthologous human gene of neural tube defect nor spina bifida to date [212]. That said, it does not mean that the studies on the structural changes afforded by the mouse model cannot be used as a tool to understand human spina bifida. We discuss the various studies on mouse neurulation below and why it is still an invaluable tool for understanding human neurulation.

8.1. Mechanisms of Neural Tube Closure. In vertebrates, the development of the CNS starts with the formation of the neural plate on the dorsal surface of the embryo during late gastrulation $[213,214]$. A complex morphogenetic process transforms the neural plate into the hollow neural tube in a process known as "neurulation" [213]. Primary neurulation is responsible for formation of the neural tube throughout the brain and the spinal cord rostral to the mid-sacral level [215]. At more caudal levels, an alternative mechanism (secondary neurulation) operates whereby the neural tube is formed by canalization of a condensed rod of mesenchymal cells in the tail bud [216].

The process of neurulation in mammals and some other vertebrates is considered discontinuous because it occurs simultaneously at multiple sites along the neuraxis [215219]. There are three points of de novo neural tube fusion in the mouse, which is the most studied mammalian model ([220]; see Figure 2(a)). Closure 1 occurs adjacent to somite 3 in embryos with 6-7 somites and progresses rostrally and caudally, closure 2 occurs at the midbrain-forebrain boundary at around the 10-somite stage and progresses caudally, and closure 3 occurs at the rostral end of the forebrain, soon after closure 2.

Considering this discontinuous process of neurulation, it can be understood why NTDs are such a complex group of heterogeneous birth defects, with various phenotypic presentations. Failure of closure 1 leads to craniorachischisis (Figure 2(b)); failure of closures 2 and/or 3 causes exencephaly and/or anencephaly, respectively (Figure 2(c)), while failure of neurulation to progress from the site of closure 1 caudally along the spinal axis leads to spina bifida aperta (Figure 2(d)).

During neurulation, the neuroepithelium must undergo various structural changes in order to achieve closure. The advent of molecular biology has allowed scientists to identify the genes that are required for these structural changes to occur. The next section gives a brief overview of the research to date on how gene expression affects structural changes in neural tube development, with an emphasis on gene regulation in the spinal region.

\subsection{The Structural Changes of the Mouse Neural Tube during} the Process of Closure. Morphologically, the mouse neural tube undergoes distinct structural changes prior to its closure [7, 215, 221-224]. A summary of the spatiotemporal expression of genes in the mouse neural tube during neurulation is as shown in Table 5. The neuroepithelium narrows and lengthens, a process referred to as convergent extension (Figure 3(a)), in which the polarized cells which form the neuroepithelial plate converge towards the midline, elongate anteroposteriorly, and then intercalate [215, 225]. 
TABLE 2: List of mouse models that exhibits spina bifida (reviewed in $[4,54])$.

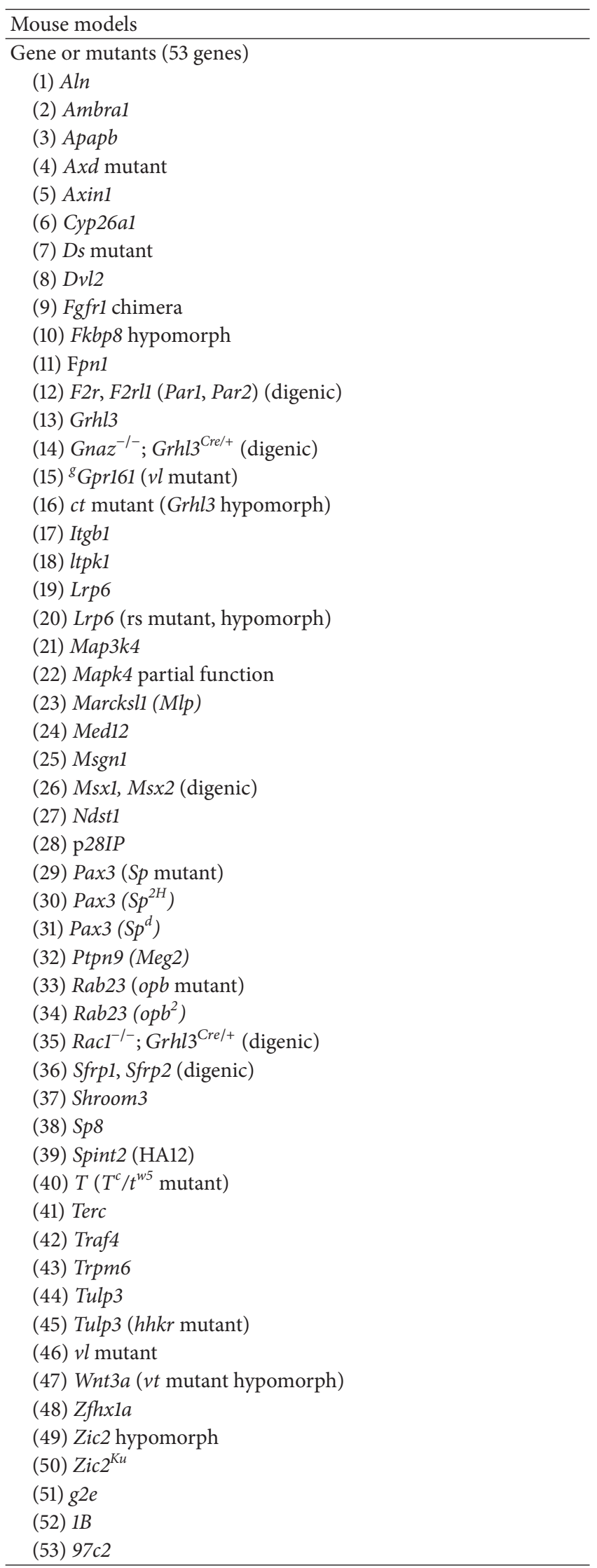

TABLE 2: Continued.

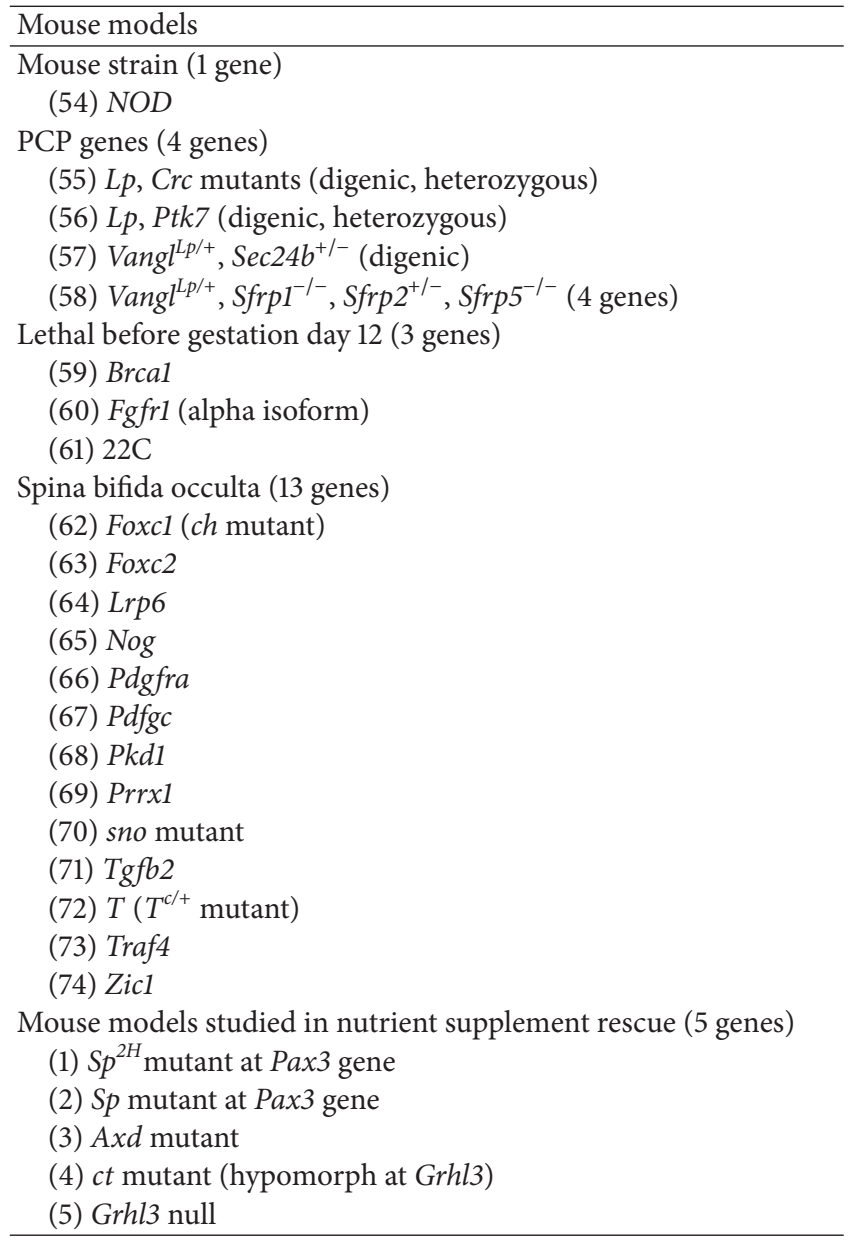

Convergent extension leads to narrowing and lengthening of the neuroepithelium, a process that has been suggested also to assist neural fold elevation via axial elongation [105, 226-228]. However, the lengthening of the body axis is disrupted by manipulation of gene function required for convergent extension; whilst the neural folds are still able to elevate, convergent extension still fails [227, 229, 230]. Hence, convergent extension and neural fold elevation are separable processes. Elevation of the neural folds at high levels of the spinal neuraxis results from the formation of a median hinge point (MHP) (Figure 3(b)) in a process termed Mode 1 neurulation $[215,231,232]$. The neural folds remain straight along both apical and basal surfaces, resulting in a neural tube with a slit-shaped lumen. Mode 1 neurulation occurs during formation of the spinal neural tube in 6-10somite stage embryos, as shown in Figures 4(a) and 4(b).

A second set of hinge points are formed dorsolaterally at more caudal levels of the spinal neuraxis, the dorsolateral hinge points (DLHPs), a process that appears to enhance the ability of the apposing tips of the neural folds to come close to each other (Figure 3(c)). Mode 2 occurs during formulation of the spinal neural tube in 12-15-somite stage embryos and generates a diamond-shaped lumen, as depicted in Figures 4(c) and 4(d). In Mode 2, a median hinge point is also present, 


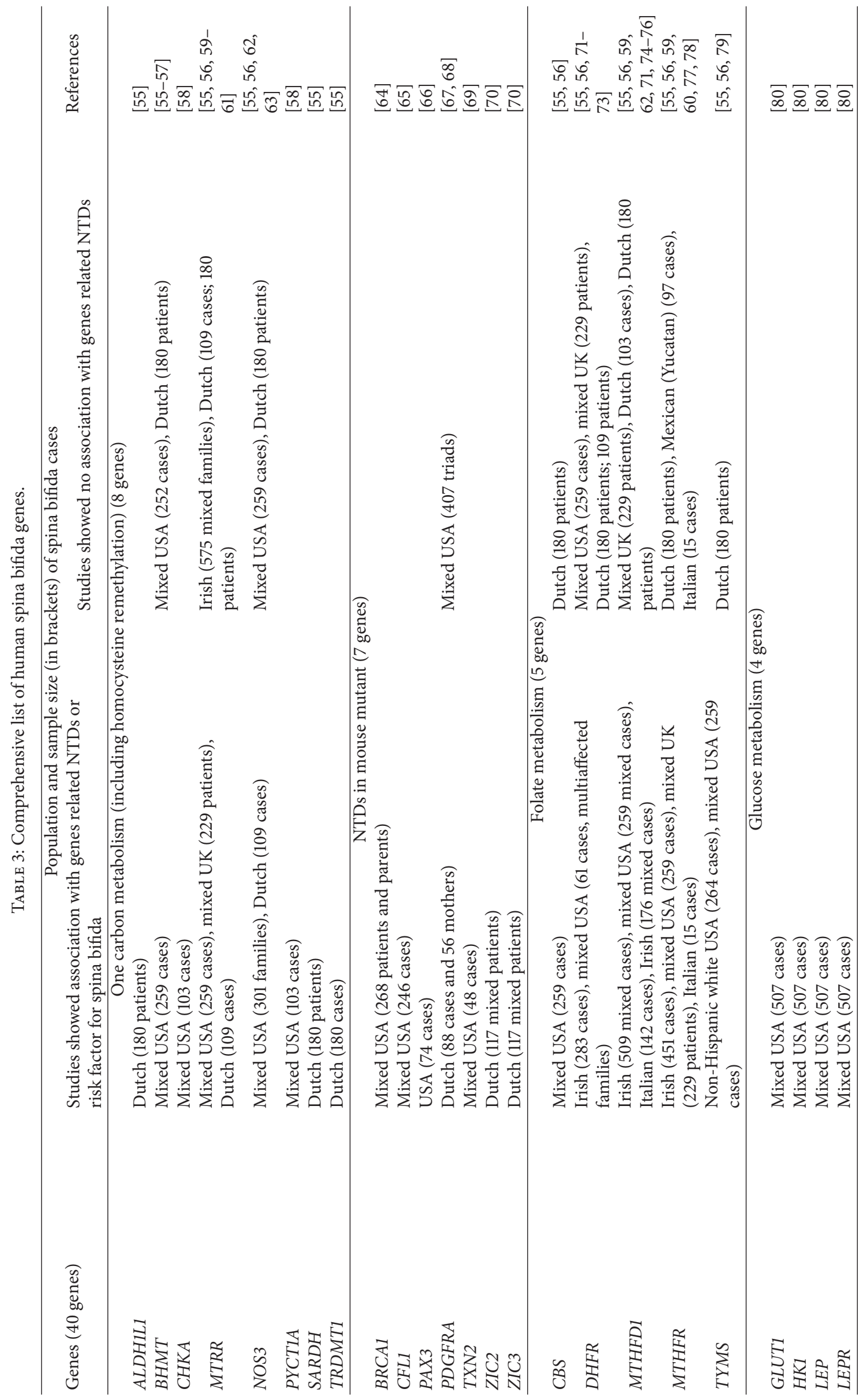




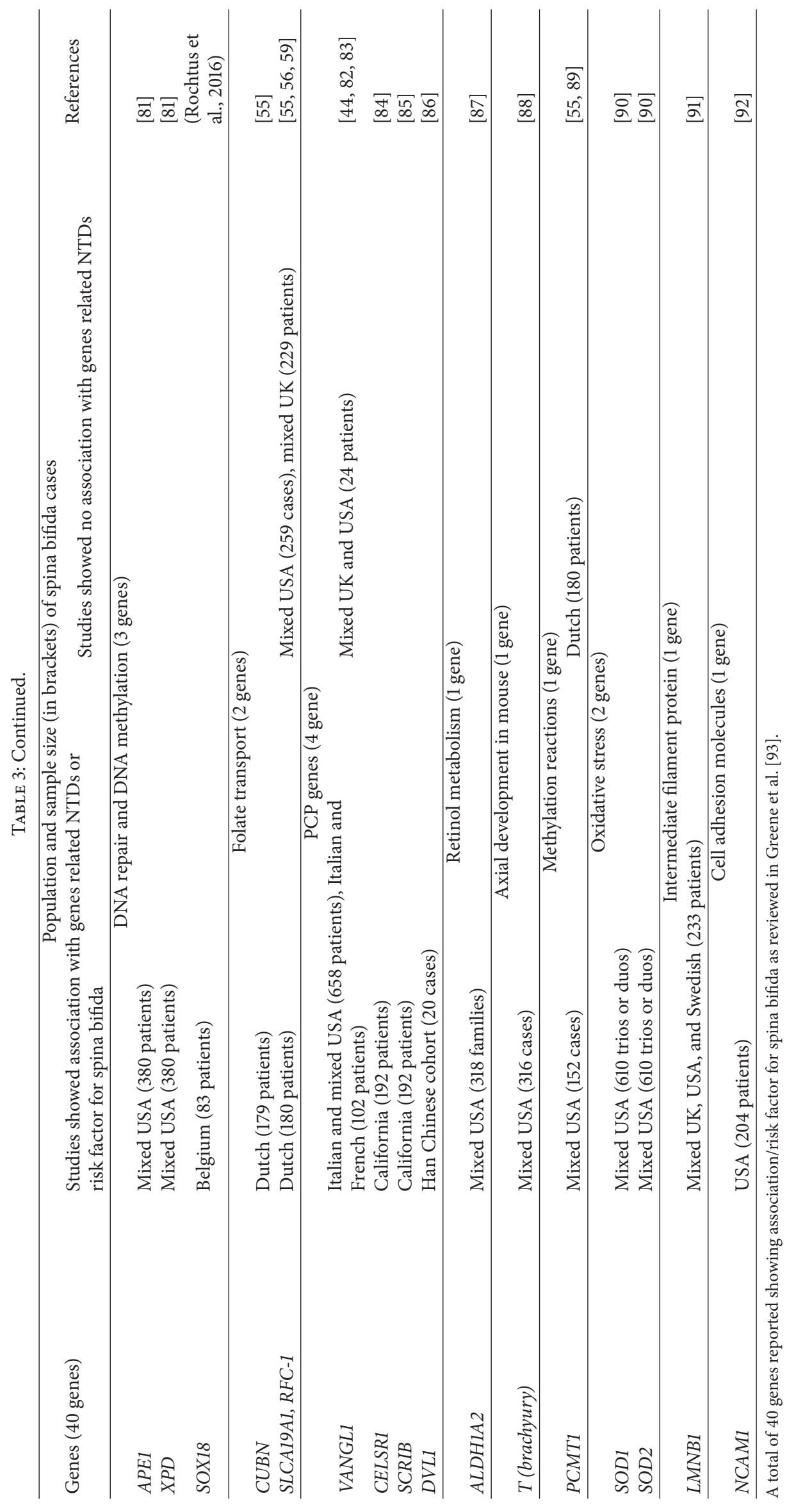




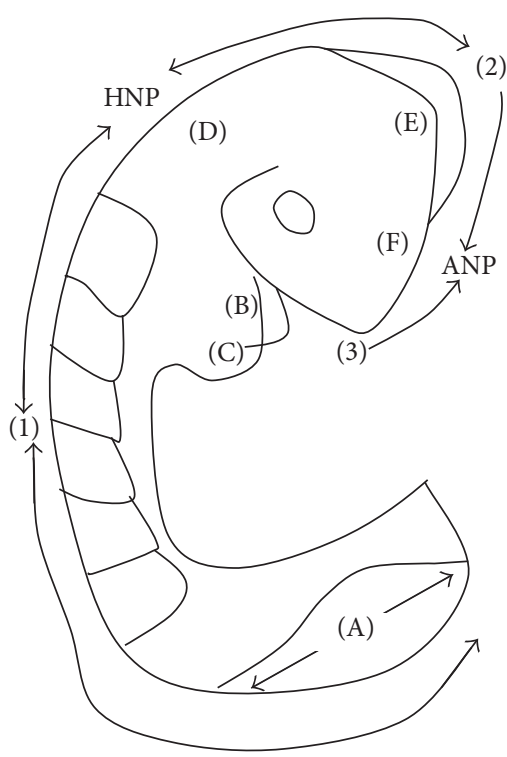

(a)

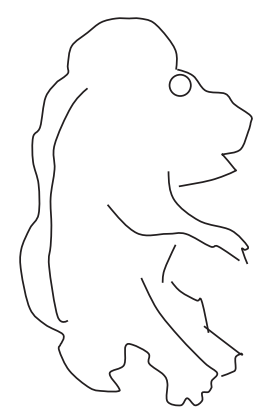

(b)

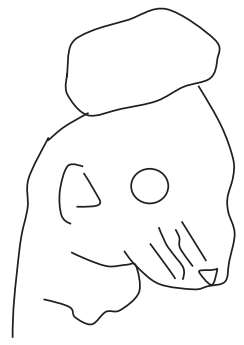

(c)

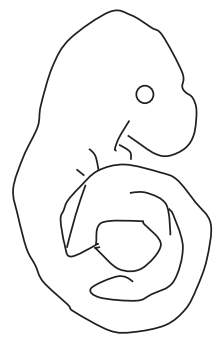

(d)

Figure 2: Points of closure in the mouse embryo and phenotypes of failure of closure of the various points along the neuraxis. (a) Schematic figure illustrating the multiple points of closure of the neural tube, directions of closure, and the different locations of neuropores in the developing embryo. (1), site of closure (1) which occurs at the level of somite 3 in the 6-7-somite embryo. Closure (1) is the initiation event of neurulation. Closure then progresses caudally and is completed by closure of the posterior neuropore (PNP) at the 29-30-somite stage of development; (2), second closure site at around the 10-somite stage; (3), closure (3) site which begins soon after closure (2). Arrows depict spreading of neural tube closure to neighbouring regions with completion of anterior neuropore closure soon after initiation of closure (3) and closure of the hindbrain neuropore at the 18-20-somite stage. (b) Phenotype resulting from failure of closure (1): craniorachischisis; (c) phenotype resulting from failure of closure (2): exencephaly; (d) phenotype of failure of the caudal wave of spinal closure, leading to an enlarged PNP and later development of spina bifida. (A), posterior neuropore; (B), branchial arches; (C), developing heart; (D), hindbrain; (E), midbrain; (F), forebrain; ANP: anterior neuropore; HNP: hindbrain neuropore.

whereas the remaining portions of the neuroepithelium do not bend. At the 17-27-somite stage, the neural tube closes without a median hinge point, whereas dorsolateral hinge points are retained. This is known as Mode 3 neurulation and generates an almost circular shaped lumen, as shown in Figures 4(e) and 4(f).

Adhesion of the tips of the apposing neural folds is the final step in primary neurulation, enabling the neural tube to complete its closure [215]. The tips of the apposing neural folds and the eventual point of adhesion are reported to contain cell to cell recognition molecules (as demonstrated in red in Figure 3(c)) which may be required for the specific adhesion process to occur [233-243]. This is supported by previous evidence that the cell surface of the neuroepithelium is lined by carbohydrate-rich material that is not observed in the rest of the neuroepithelium [238]. Removal of
GPI-anchored proteins from the cell surface during neurulation results in delayed spinal neural tube closure [244]. Interestingly, work performed by Abdul-Aziz et al. and Pyrgaki et al. demonstrated protrusions emanating from the neural fold tips that interdigitate leading to eventual adhesion $[244,245]$ (Figure 3(d)). Ultimately, the newly formed neural tube undergoes remodelling via apoptosis to enable the neural tube to separate from its surface ectoderm $[228,246]$ (Figure 3(e)).

8.3. Primary Neurulation Versus Secondary Neurulation. Primary neurulation and secondary neurulation are important developmental processes and have been described in many models. In the chick, there does not exist a clear distinction as to when primary neurulation ends and secondary neurulation begins; the lower spinal cord has been described 


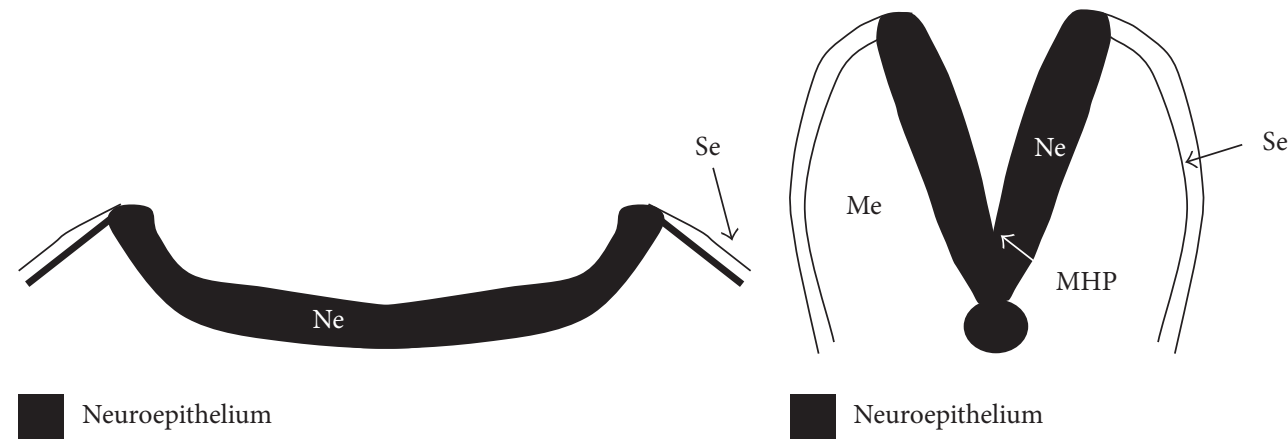

(a)

(b)

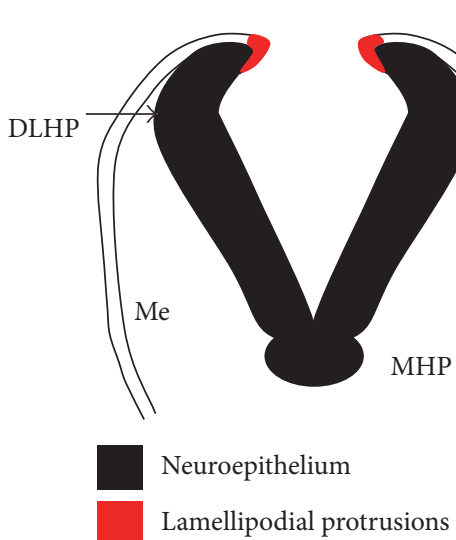

(c)

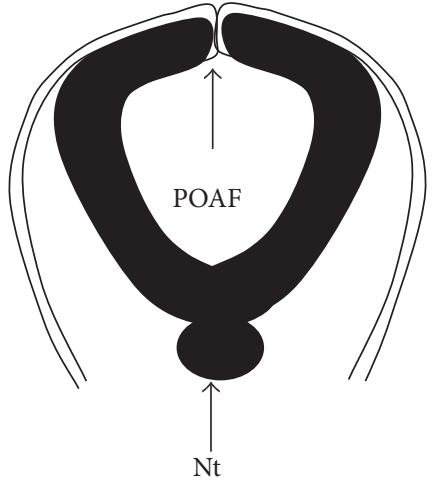

Neuroepithelium

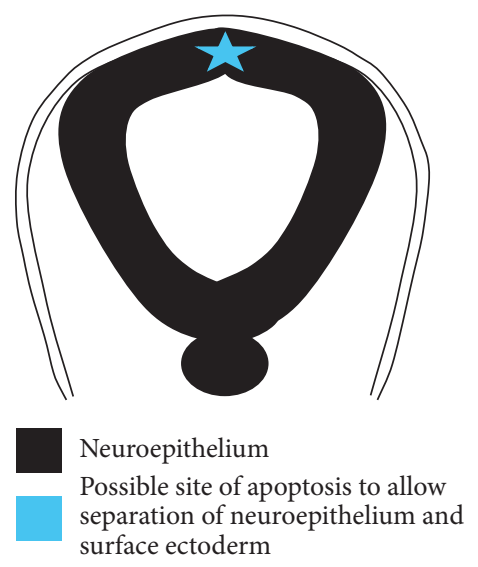

(e)

FIgURE 3: Schematic representation of the formation of the mouse spinal neural tube. Process of closure of the PNP of embryos undergoing Mode 1 ( $a, b, d$ ) or Mode 2 (a, c, d) neurulation. (a) Neuroepithelium thickens and converges; (b) formation of bilateral neural folds which are elevated (Mode 1); (c) apposing tips of neural folds aided by bending at the dorsolateral hinge points (DLHP) of the bilateral neural folds (Mode 2); (d) adhesion and fusion at the tips of the neural folds; (e) remodeling of the neural tube. Ne, neuroepithelium; Se, surface ectoderm; $\mathrm{Me}$, mesoderm; MHP, median hinge point; DLHP, dorsolateral hinge points; POAF, point of adhesion and fusion; Nt, notochord.

as junctional neurulation, whereby ingression and accretion accompany the process of defining the area which straddles primary and secondary neurulation and is therefore thought to somehow represent human thoracolumbar spina bifida [247].

In mouse and humans, spina bifida occulta has largely been described as a result of failure of secondary neurulation $[3,215]$. However, much has been described of the severity of lipomyelomeningocele $[131,248]$ in comparison to the somewhat neurologically unperturbed tethered cord phenomenon which is brought on by trapped nerves due to missing vertebral arches [133]. What is evident is that, irrespective of whether or not there is skin covering the neural tube defect lesion, the severity of the condition depends on the level where the site of the lesion is located. Secondary neurulation in the mouse is described as occurring at sacral level 2 [224]. 


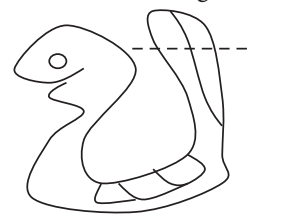

- - Level of spinal axis sectioned

(a)

12-15-somite stage (E9.5)

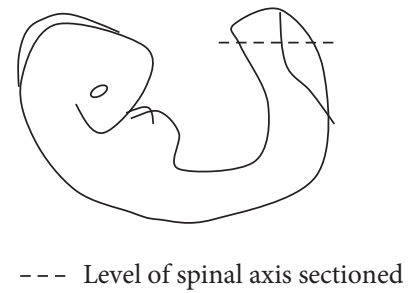

(c)

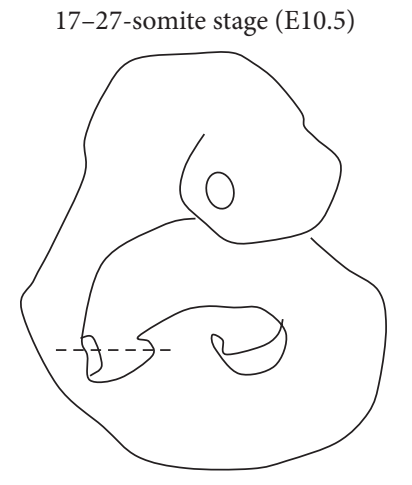

- - - Level of spinal axis sectioned

(e)

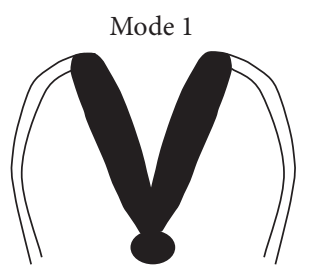

(b)

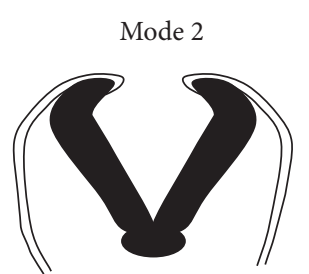

(d)

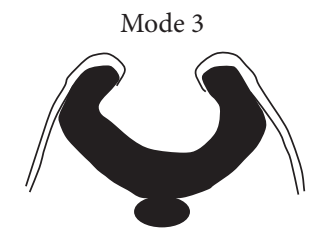

(f)

FIGURE 4: Schematic figure showing progressive developmental stages of the mouse embryo and sections through the PNP at these stages. (a) Schematic of embryo at 6-10-somite stage, which has already undergone closure (1); (b) section through PNP of (a), depicting Mode 1 neurulation; (c) schematic of embryo at 12-15-somite stage; (d) section through PNP of (c) exhibiting Mode 2 neurulation; (e) schematic of embryo which has undergone closures (1), (2), and (3) with PNP being the only remaining unfused section of the neural tube; (f) section through PNP of (e) depicting Mode 3 neurulation.

Therefore, to describe lipomyelomeningocele as resulting from failure of secondary neurulation would be artificial.

\section{The Genetics behind the Structural Changes in Spinal Neural Tube Closure}

This section summarizes the various genes that are switched on during neurulation and whose functions have been implicated in the various structural changes that the spinal neural tube undergoes in order for closure to be achieved.

9.1. Planar Cell Polarity and Convergent Extension. Planar cell polarity (PCP) is a process in which cells develop with uniform orientation within the plane of an epithelium [249]. The PCP pathway is a noncanonical Wnt pathway [225, 250-252].
Various Wnt molecules are known to play roles in the PCP pathway such as Wnt11 and Wnt5a [250, 253].

PCP signaling has been suggested to be primarily required for cytoskeletal activity, for example, cellular protrusion, cell-cell adhesion, and cell-matrix adhesion [254]. Skin development, body hair orientation, polarization of the sensory epithelium in the inner ear, and the directed movement of mesenchymal cell populations during gastrulation are among the processes requiring proper PCP signaling in vertebrates [227, 254-256]. In vertebrates, function of the PCP pathway appears to be required for convergent extension (CE). Lamellipodia have been the type of cell shown to drive CE. These broad sheet-like protrusions exert traction on adjacent mesodermal cells causing mediolateral intercalation [257-259]. PCP signaling causes the regulation of cytoskeletal 
organization that redistributes subcellular PCP components asymmetrically causing polarization of these cells [260]. Moreover, components of the signaling cascade converge or are expressed asymmetrically in the lamellipodia $[250,253]$.

Among the genes implicated in this net movement of cells, known as convergent extension, are 2 asymmetric molecular systems that control PCP behaviour, the "core" genes and the "Fat-Dachsous" PCP system [261, 262]. The "core" genes give rise to multipass transmembrane proteins: Frizzled (Fzd-3, -6, and -7), Van Gogh (Vangl-1 and -2), Flamingo (Celsr-1, -2, and -3), and cytosolic components, Dishevelled (Dvl-1, -2, and -3), Diego (Inversin), and Prickle (Pk-1 and -2) [263]. The Fat-Dachsous (Ft-Ds) pathway includes the large protocadherins Ft and Ds, acting as its ligand, and Four-jointed ( $\mathrm{Fj}$ ) as a Golgi resident transmembrane kinase [264]. Downstream of the PCP system are PPE (Planar Polarity Effector) genes: Inturned (In), Fritz (Frtz), and Fuzzy (Fy) $[265,266]$. The Multiple Wing Hairs (mwh) act downstream of both PCP and PPE [267] with Wnt4, Wnt5a, Wnt7a, and Wnt11 as regulators [263].

Vangl-2 (formerly known as Ltap and Lpp1) has been identified as the causative gene in the loop-tail mouse $[105,268,269]$. Mutations in Celsr-1 cause craniorachischisis in the Crash mouse [270]. The Dvl-1/Dvl-2, Dvl2/Dvl-3, Dvl-2/Vangl-2, and Fzd-3/Fzd-6 double knockout mice also have severe NTD forms, mainly craniorachischisis and exencephaly [269, 271-273]. The Vangl-1 and Vangl2 compound heterozygote exhibits craniorachischisis [274]. The noncore PCP genes also exhibit severe NTD in their mouse mutants including Protein Tyrosine Kinase 7 (PTK7), Scribbled PCP protein, the gene responsible for the circle tail mouse phenotype, Scrib, and Dishevelled Binding Antagonist of Beta-Catenin 1 (Dact-1) [252, 270, 274-277]. All of these genes have been implicated in the PCP pathway. Failure of convergent extension results in an open neuraxis (the entire neural tube from midbrain to low spine remains exposed) and a shortened embryo, more commonly described as craniorachischisis.

9.2. Neural Fold Elevation and Bending. Dorsoventral patterning in the neural development of vertebrates is controlled by the induction and polarizing properties of the floor plate [278]. Expression of various genes such as sonic hedgehog (Shh), bone morphogenetic protein (BMP) 7, HNF3 $\beta$, and Vangl-1 emanating from the notochord and floor plate is thought to cause cell specification which influences the morphogenesis of the neural tube [106, 107, 112, 113, 252]. The floor plate and notochord appear to control the pattern of cell types that appear along the dorsoventral axis of the neural tube [226, 278]. Morphogenesis of the spinal neural tube, in particular, the formation of the median hinge point (MHP), is most likely a nonneuroepithelial cell autonomous action as it is dependent on the differentiation of ventral cell types by signals transmitted from axial mesodermal cells of the notochord to overlying neuroepithelial cells [278-284].

Implantation and ablation experiments which manipulated the notochord in both chick and mouse embryos [221, 284-287] verified that the notochord is required for formation of the MHP. It was proposed that the notochord releases a morphogen that may regulate MHP formation. Shh protein is expressed in the notochord at this stage $[113,288]$ and application of either Shh-expressing cells or purified protein to intermediate neural plate explants leads to induction of the floor plate [113], suggesting that Shh is the MHP-inducing morphogen. However, MHP formation is not totally abolished in Shh-null mouse embryos, suggesting that other factors from the notochord may also have MHPinducing properties [287].

The second site of neural fold bending as described in Section 8.2 and Figure 3(c) is the dorsolateral hinge point (DLHP). Bending of the neuroepithelium at the DLHP is regulated by mutually antagonistic signals external to the neural fold, as reviewed by Greene and Copp [224, 289]. In contrast to midline bending, Shh has been shown to inhibit dorsolateral bending in the mouse [287] consistent with an absence of NTDs in Shh-null embryos. Signal(s) arising from the surface ectoderm (SE) comprise(s) a second antagonistic signal involved in the regulation and formation of the DLHPs [290]. This has been suggested as further evidence that bending of the neural folds involves signaling from the SE. Bone morphogenetic proteins (BMPs) are candidates to mediate this signaling. Three BMPs (BMP2, $B M P 4$, and $B M P 7)$ are expressed in the spinal neural tube. $B M P 2$ and $B M P 7$ are expressed in the surface ectoderm adjacent to the open spinal neural tube, while $B M P 4$ is expressed in the surface ectoderm overlying the closed spinal neural tube [291].

Recent studies suggest that Noggin may also play a role in regulating DLHP formation [292, 293]. Noggin is an inhibitor of BMP signaling and is expressed at the tips of the apposing neural folds [293, 294]. Homozygous mouse embryos null for Noggin exhibit both exencephaly and spina bifida (100\%) [292, 295]. However, spina bifida does not arise in homozygous Noggin mutants until embryonic day 11-12 when the neural tube ruptures. The spinal neural tube of homozygous null Noggin embryos during neurulation takes on the appearance of a wavy neural tube before the neural tube reopens [293], possibly suggesting an unstable initial closure mechanism. Shh works in an antagonistic manner towards Noggin, as does Noggin towards BMP signaling [296]. This suggests that Noggin may facilitate bending of the spinal neural tube [293] by overcoming the inhibitory influence of $B M P$ s.

Stottmann et al. [293] suggest that the spinal defect in Noggin null embryos results from a failure to maintain a closed neural tube due to a defective paraxial mesoderm [293]. Yip et al. [297] also had shown that the mesodermal extracellular matrix plays an important role in maintaining neuroepithelial rigidity of the spinal neural tube during neurulation [297]. Embryos were cultured in the presence of chlorate, which functions to inhibit sulfation of heparan sulphate proteoglycans (HSPGs) in the extracellular matrix of the mesoderm. This treatment not only resulted in an expedited bending of the DLHPs but also elicited an unnatural shape of neural tube due to a convex shaped mesoderm. However, removal of the paraxial mesoderm does not prevent closure of the spinal neural tube [287].

Interestingly, there are 3 genes which, when mutated, not only affect paraxial mesoderm production in the mouse [109, 
292, 298] but also result in an NTD phenotype in the mouse. These are Cyp26, Noggin, and Fgfr1 [94, 109, 293]. The Wnt3a [299], Lef1/Tcf1 double null [108] and Raldh2 [300] mutants also have defective paraxial mesoderm production, with an abnormal neural tube during neurulation. Whether or not the paraxial mesoderm plays a primary role in successful neurulation in these mutants remains unknown.

Neural tube closure does not depend exclusively on the MHP or DLHPs, since closure can occur in the absence of either, as in Mode 3 and Mode 1 spinal neurulation, respectively. However, cell shape changes of some type, affecting morphogenesis of the spinal neural tube, are clearly required for closure to occur in all species studied, including the mouse [254]. Table 5 demonstrates the lack of specific expression of genes at the DLHPs. However, overlapping gene expression throughout the neuroepithelium and tips of neural folds may facilitate the bending mechanism seen in the DLHPs.

9.3. Adhesion of the Neural Folds. In all animal species studied, a zone of altered cell morphology with numerous rounded cell blebs has been observed along the tips of the spinal neural folds, immediately prior to adhesion. The observed surface alterations may reflect a change in the properties of the cells at the adhesion site which correlate with initial adhesion between the folds [234, 236, 301, 302]. Structural observations of the point of adhesion in human embryos have yet to be reported, possibly due to insufficient or poor preservation of material so that surface structures cannot be observed.

Adhesion is the final process in the sequence of primary neurulation events. Such physical zippering state of the neural tube has been suggested, in previous studies, as evidence that neural tube closure is a continuous process [303]. However, a debate exists as to whether the physical process of neurulation actually equates to continuous zippering or, more accurately, to a button-like process in which neural tube adhesion initially occurs at various slightly separated points along the axis. According to the latter idea, neural tube adhesion is actually a discontinuous process of closure [222].

PCP regulation may play a role in adhesion and fusion as suggested in both zebrafish and Xenopus studies. Firstly, cell division regulated by PCP signaling leads to rescue of neural tube morphogenesis in the trilobite zebrafish mutant [304]. Secondly, the Xenopus adhesion molecules, NF-protocadherin, and its cytosolic partner TAF1/Set have been suggested to participate in CE after the neural folds are formed. Disruptions in NF-protocadherin and TAF1 can lead to a shortened AP axis that was not evident until stages 22-25, some time after neural tube closure [305].

Ultrastructures that emanate from the neural folds at the site of closure have been regarded as a secondary process in the frog. This is because wound healing which acts via actin purse-string contraction is thought to be the primary cause of closure in the frog neural tube [306]. Adhesion of the neural tube and epidermis have been suggested to be separate events based upon the observation that the epidermal ectoderm is still able to migrate and cover the open neural tube in both the chick and the frog $[302,305]$. However, the issue of whether or not the neural folds could adhere even in the absence of epidermal fusion in both the chick and the frog has yet to be answered.

Adhesion in the neural tube of rodents has been described previously but the mechanism of this highly specialized process is poorly understood [103, 240, 243, 301, 307, 308]. In a recent study, a direct requirement was shown for the binding of a specific ligand (ephrinA5) to a specific type of receptor (EphA7) in order to enable adhesion to occur in the neural tube [243].

Cell to cell adhesion provides impetus for positional cell migration [309]. This may suggest that PCP driven events in the surface ectoderm may play a role in neural tube closure, as suggested in the chick embryo [310]. Epidermal constriction has also been shown to be crucial for spinal neural tube closure in the frog, while the surface ectoderm was shown to be necessary for spinal neural tube closure in the mouse $[287,311]$.

\section{Mouse Mutant Models with a Spinal Defect, Not a Neural Tube Defect}

Table 4 summarizes the ten mouse mutant models that exhibit a spinal defect alone. Spinal defects encompass mouse mutants with spina bifida (without any other NTD phenotype, e.g., exencephaly and/or craniorachischisis) and abnormal spinal neural tubes with no spina bifida.

The mutants which display only spina bifida are the FGFR1 $\alpha$ chimeric mutant [94], Traf4 mutant [95], the Shp2 chimeric mutant [96], the axial defects mutant [97], glial cell missing-1 [98], and vacuolated lens [99].

All of these mutants have spina bifida, which denotes incomplete closure of the spinal neural tube. A large majority ( 4 out 6 of these mutants which have only spina bifida) have a second phenotype that is a second neural tube. Vacuolated lens mutant embryos develop spina bifida and, in addition, an ectopic neural tube is observed, ventral to the open neural tube [99]. In Shp2, FGFR1 $\alpha$, and vacuolated lens mutants, an ectopic neural tube is observed during the period of neurulation between E8.5 and E9.5 [94, 96]. In contrast, an ectopic neural tube has only been observed at E12.5 and later stages in $\mathrm{Gcml}$ mutant embryos [98].

The prevalence of an ectopic neural tube in 2 out of 6 mutants at E9.5-E10.5 seems to suggest that a second neural tube may be a common occurrence and that this predisposition may be the result of an underlying fault in primary neurulation instead of failure of secondary neurulation.

There are many different examples of mouse mutants in which the caudal neural tube is abnormal but the phenotype differs from spina bifida. In many cases, these are described as spinal neural tube defects [100-103]. Apart from the 3 mutants with only spina bifida (Fgfrl, Shp2, and Gcml) which have 2 neural tubes with one notochord, 2 other mutants with spinal defect but no spina bifida share the same predicament. These are the EphA2 null mouse [101] and PAK4 null mouse [100]. Another abnormal spinal neural tube phenotype is a wavy spinal neural tube that occurs in the WASP null mouse and the Vinculin null mouse [102, 103]. Vinculin is a large 
TABLE 4

\begin{tabular}{|c|c|c|c|c|c|c|}
\hline Mutant name & $\begin{array}{c}\text { Gene } \\
\text { mutated }\end{array}$ & $\begin{array}{l}\text { Function of } \\
\text { protein }\end{array}$ & $\begin{array}{c}\text { Possible } \\
\text { mechanism } \\
\text { of NTD }\end{array}$ & $\begin{array}{l}\text { Schematic representations of } \\
\text { ectopic spinal neural tube }\end{array}$ & $\begin{array}{c}\text { Rate of } \\
\text { occurrence of } \\
\text { spina bifida }\end{array}$ & $\begin{array}{l}\text { Phenotype } \\
\text { and reference }\end{array}$ \\
\hline $\begin{array}{l}\text { Fibroblast } \\
\text { growth factor } \\
\text { receptor } 1 \\
\text { (knockout } \\
\text { producing } \\
\text { chimeras) }\end{array}$ & $F g f r 1$ & $\begin{array}{l}\text { Growth factor } \\
\text { receptor }\end{array}$ & $\begin{array}{l}\text { Unknown } \\
\text { (NTDs occur } \\
\text { only in } \\
\text { chimaeras) }\end{array}$ & & $\begin{array}{c}\text { E10.5, } 29.5 \% \\
\text { have spina } \\
\text { bifida and } \\
\text { 15\% have } \\
\text { ectopic } \\
\text { neural tube }\end{array}$ & $\begin{array}{c}\text { Spina bifida, } \\
\text { second NT; } \\
\text { NT in NT \& } \\
\text { kinky tail } \\
\text { [94] }\end{array}$ \\
\hline
\end{tabular}

\section{Tumour}

necrosis factor

receptor associated factor

4

(knockout) Traf4 $\begin{gathered}\text { Intracellular } \\ \text { signaling adaptor }\end{gathered}$
Unknown

No ectopic neural tube
$40 \%$

homozygous nulls have spina bifida
Spina bifida [95]

\begin{tabular}{|c|c|c|c|c|c|c|}
\hline $\begin{array}{l}\text { Shp2 } \\
\text { (knockout } \\
\text { producing } \\
\text { chimeras) }\end{array}$ & $\operatorname{Sh} p 2$ & $\begin{array}{c}\text { Tyrosine } \\
\text { phosphatase } \\
\text { (dephosphorylates } \\
\text { proteins) }\end{array}$ & $\begin{array}{l}\text { Unknown } \\
\text { (NTDs occur } \\
\text { only in } \\
\text { chimaeras) }\end{array}$ & 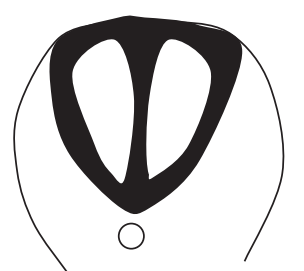 & $\begin{array}{c}\text { E10.5, } 36 \% \text { of } \\
\text { high content } \\
\text { chimeras } \\
\text { have second } \\
\text { neural tube } \\
\text { and } 59 \% \text { have } \\
\text { spina bifida }\end{array}$ & $\begin{array}{c}\text { Spina bifida, } \\
\text { second NT } \\
{[96]}\end{array}$ \\
\hline $\begin{array}{l}\text { Axial defects } \\
\text { (spontaneous } \\
\text { mutant; gene } \\
\text { not identified) }\end{array}$ & ND & ND & ND & No ectopic neural tube & $\begin{array}{c}10 \% \\
\text { penetrance in } \\
\text { CD1 }\end{array}$ & $\begin{array}{c}\text { Spina bifida } \\
\text { [97] }\end{array}$ \\
\hline $\begin{array}{l}\text { Glial cells } \\
\text { missing-1 } \\
\text { (knockout) }\end{array}$ & Gcm1 & $\begin{array}{l}\text { Transcription } \\
\text { factor }\end{array}$ & $\begin{array}{c}\text { Ectopic } \\
\text { expression } \\
\text { causes NTDs } \\
\text { by unknown } \\
\text { mechanism }\end{array}$ & and & $\begin{array}{c}25.8 \% \\
\text { transgenics } \\
\text { have spina } \\
\text { bifida; } 100 \% \\
\text { transgenics } \\
\text { have ectopic }\end{array}$ & $\begin{array}{c}\text { Spina bifida; } \\
\text { multiple NT } \\
{[98]}\end{array}$ \\
\hline $\begin{array}{l}\text { Vacuolated lens } \\
\text { (spontaneous } \\
\text { mutant) }\end{array}$ & ND & ND & $\begin{array}{l}\text { Suggested } \\
\text { failure in } \\
\text { apposition } \\
\text { and fusion? }\end{array}$ & & $\begin{array}{c}50 \% \text { of } \\
\text { homozygous } \\
\text { nulls show } \\
\text { spina bifida at } \\
12 \mathrm{dpc}\end{array}$ & $\begin{array}{c}\text { Spina bifida } \\
\text { [99] }\end{array}$ \\
\hline
\end{tabular}


TABLE 4: Continued.

\begin{tabular}{|c|c|c|c|c|c|c|}
\hline Mutant name & $\begin{array}{c}\text { Gene } \\
\text { mutated }\end{array}$ & $\begin{array}{l}\text { Function of } \\
\text { protein }\end{array}$ & $\begin{array}{c}\text { Possible } \\
\text { mechanism } \\
\text { of NTD }\end{array}$ & $\begin{array}{l}\text { Schematic representations of } \\
\text { ectopic spinal neural tube }\end{array}$ & $\begin{array}{c}\text { Rate of } \\
\text { occurrence of } \\
\text { spina bifida }\end{array}$ & $\begin{array}{l}\text { Phenotype } \\
\text { and reference }\end{array}$ \\
\hline $\begin{array}{l}\text { PAK4 } \\
\text { (knockout) }\end{array}$ & PAK4 & $\begin{array}{l}\text { Cytoskeletal } \\
\text { organization }\end{array}$ & $\begin{array}{c}\text { Target for } \\
\text { Rho GTPase } \\
\text { Cdc42 }\end{array}$ & & None & $\begin{array}{l}\text { with one } \\
\text { notochord } \\
\text { No spina } \\
\text { bifida } \\
\text { [100] }\end{array}$ \\
\hline $\begin{array}{l}\text { EphA2 } \\
\text { (knockout) }\end{array}$ & EphA2 & $\begin{array}{l}\text { Adhesion and } \\
\text { fusion? }\end{array}$ & $\begin{array}{l}\text { Receptor } \\
\text { tyrosine } \\
\text { kinase }\end{array}$ & & None & $\begin{array}{c}\text { Kinky tail } \\
\text { with double } \\
\text { neural tube } \\
\text { No spina } \\
\text { bifida } \\
{[101]}\end{array}$ \\
\hline $\begin{array}{l}\text { WASP } \\
\text { (knockout) }\end{array}$ & WASP & $\begin{array}{l}\text { Cytoskeletal } \\
\text { organization }\end{array}$ & $\begin{array}{l}\text { Formation of } \\
\text { cell-surface } \\
\text { projections } \\
\text { (filopodia) } \\
\text { required for } \\
\text { cell } \\
\text { movement } \\
\text { and } \\
\text { actin-based } \\
\text { motility }\end{array}$ & & None & $\begin{array}{c}\text { Wavy neural } \\
\text { tube } \\
\text { No spina } \\
\text { bifida } \\
\text { [102] }\end{array}$ \\
\hline
\end{tabular}

Vinculin

(knockout) (E10 Lethal)
Vinculin

Cytoskeletal organization

\section{Major}

constituent of

cell junctions

(cell matrix \& cell-cell)

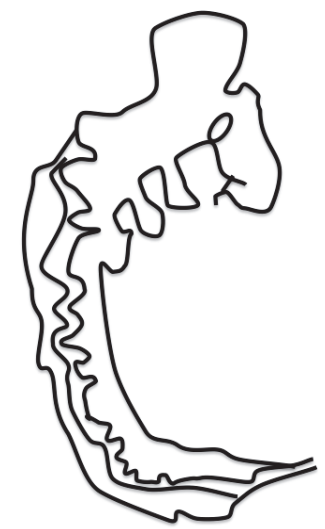

Wavy neural tube No spina bifida [103] 
TABLE 5

\begin{tabular}{|c|c|}
\hline \multirow[t]{9}{*}{ Neural tube structure } & Genes expressed at $\square$ \\
\hline & $\begin{array}{l}\text { Neuroepithelium } \\
\quad \text { Zic2 [104] } \\
\text { Vangl2 [105] }\end{array}$ \\
\hline & $\begin{array}{l}\text { Floor plate and notochord } \\
\text { HNF3 }[106] \\
\text { Vangl1 }[107] \\
\text { Wnt3a }[108] \\
\text { Cyp26a1 }[8,109] \\
\text { Shh }[11] \\
\text { Map3k4 [110] } \\
\text { Marcksl1 (Mlp) }[18,111] \\
\text { Traf4 }[21,95]\end{array}$ \\
\hline & $\begin{array}{l}\text { Notochord } \\
\quad \text { BMP7 [112] } \\
\text { Brachyury [6] } \\
\text { Shh }[10,11,113,114]\end{array}$ \\
\hline & $\begin{array}{l}\text { Surface ectoderm } \\
\text { Fgf8 [115] } \\
\text { Grainyhead-like } 2 \text { [116] } \\
\text { BMP7 [104] } \\
\text { Wht6 [104] } \\
\text { Notch1 [108] }\end{array}$ \\
\hline & $\begin{array}{l}\text { Dorsolateral hinge points } \\
\text { None }\end{array}$ \\
\hline & $\begin{array}{l}\text { Tips of neural folds at E9.5 } \\
\quad \text { Axin2 [117] } \\
\quad \text { Pax3 [118] }\end{array}$ \\
\hline & $\begin{array}{l}\text { Dorsal roof of closed neural tube bridge } \\
\quad \text { Zic2 } 2104] \\
\text { Msxi }[104] \\
\text { Wht1 }[9,119] \\
\text { BMP6 }[119]\end{array}$ \\
\hline & $\begin{array}{l}\text { Tips of neural folds (surface ectoderm) } \\
\text { Grainyhead-like 3 (in neural ectoderm at E8.5) [116] } \\
\text { Parl and Par2 [120] }\end{array}$ \\
\hline
\end{tabular}


protein that binds multiple cytoskeletal proteins, actin, $\alpha$ actinin, talin, paxillin, VASP, ponsin, vinexin, and protein kinase $\mathrm{C}$ (PKC) which have been suggested to be the adhesion scaffold that connects early adhesion sites to actin-driven protrusive machinery in enabling motility [312].

Abnormal and ectopic spinal neural tubes may be regarded as variant forms of NTDs as it may be possible that the neural tube reopens after closure due to various reasons. Ectopic neural tube may take on many different variations apart from the expected second or multiple neural tubes. Among them are a neural tube positioned above another neural tube as well as a wavy neural tube phenotype that is observed in many knockout mice with NTDs. The wavy region in these knockout mice has not had its spinal neural tube sectioned; thus it remains unknown whether the neural tube remains adhered. Spina bifida occulta in humans is usually accompanied by various physical abnormalities such as lipoma, rachischisis, hair tufts, ectodermal sinuses, skin pigmentation, or diastematomyelia. These associated defects occur in either syndromic or nonsyndromic NTDs. However, they may be missed and not categorized properly in cases of transgenic mice with possible NTDs. There is only one example of a null mouse in which these abnormalities have been well described which is the $\mathrm{Gcml}$ mouse mutant that exhibits both open (meningomyelocele) and close (lipoma and diastematomyelia) spina bifida in its litters [98].

\section{Haploinsufficiency in Mouse and Man}

Haploinsufficiency is poorly studied in both man and mouse. Furthermore, the study of the occurrence of spina bifida in genes acting in an additive or subtractive manner is almost unknown. Currently, there are 5 studies in the mouse, which have demonstrated spina bifida and the interaction of the involved genes mechanistically. These include Lrp6 and Wnt5a [313], Zac1 and Suz12 [314], Hira and Pax3 [315], Rybp encompassing Ring1 and YYP1 [316], and haploinsufficiency of the components in the primary cilium of the hedgehog pathway [317].

The scenario in humans is somewhat similar in that there are 4 studies to date demonstrating the involvement of haploinsufficiency in the causation of spina bifida. The Pax3 gene and the EphA4 gene act in concert with each other in causing spina bifida due to interstitial deletion at position $2 q 36$ [318]. Furthermore, in the same paper, Goumy et al. [318] suggested that a similar phenomenon occurs in the mouse when taking into account the spina bifida phenotype seen on the Splotch mouse that is affected by both Pax3 [93] and EphA4 [319], albeit the link between the two in the mouse has yet to be ascertained. The hedgehog pathway has also been implicated in humans, where spina bifida occurs when Patched is perturbed when implicated with Gorlin syndrome [320]. The third and fourth studies implicating human spina bifida involve haploinsufficiency in the region of $13 q$ [321] and 7q [322].

\section{Conclusion}

This review paper aims to probe spina bifida, the surviving form of neural tube defects, closely and to analyze the relationship of what can be learnt from the mouse model of spina bifida and to use that knowledge in order to shine a brighter understanding with regard to the human form.

What is very obvious is that there have been a multitude of genes (74 according to this review) which regulate specifically spina bifida in the mouse. This is a very high number of genes; therefore the take home message would be in our opinion that there are a multitude of genes that can, if perturbed, cause spina bifida. Whether or not these genes cause the condition or are in fact a player in a pool of numerous genes, which can do the job of closing the spinal neural tube, is a tantalising idea. Therefore, we put forth the idea that perhaps these 74 may be working with other genes in their family or other genes which share a common pathway in order to close the neural tube. Furthermore, the idea of gene-gene interaction which promotes heterogeneity among genes is incomplete without also considering the idea of haploinsufficiency of genes, where many mutations in mankind are somehow protected from having a deleterious phenotype by having other genes compensate the job of the gene or genes being perturbed. A very good example of this would be the Vangl1 and Vangl-2 compound heterozygote mouse mutant which lacks a single allele of both Vangl-1 and Vangl-2; therefore the probability that the 2 genes compensate each other is high and both genes are required in a certain amount of dose, lack of which translates into a neural tube defect phenotype. Therefore, the mouse model which examines the delineation of genes has not completed its true worth until scientists understand the biology of the disease or condition better by also taking into account (i) the amount (the functioning allele) of the said gene and (ii) the interaction with other genes in its family which may be able to compensate its function as well as (iii) the interaction with other genes which share a common pathway. The mouse is a powerful tool to study spina bifida because it is a mammal like humans and its embryology is similar to humans and therefore it is an indispensable tool to mechanistically study the structural changes involved in spinal neural tube closure. The genes involved in spinal neural tube defects may differ in man and mouse; however, parallels may be drawn between the principles of how the genes interact in influencing spinal neural tube closure in both man and mouse.

\section{Competing Interests}

The authors declare that they have no competing interests.

\section{Acknowledgments}

This paper is supported by High Impact Research Grant from the University of Malaya to Noraishah M. Abdul-Aziz (UM.C/ 625/1/HIR/062-J-20011-73595 and UM.C/625/1/HIR/148/2-J20011-73843), High Impact Research Grant from the Ministry of Higher Education Malaysia to Noraishah M. AbdulAziz (UM.C/625/1/HIR/MOHE/MED/08/04-E-000032), and postgraduate grant from University of Malaya to Siti W. Mohd-Zin and Noraishah M. Abdul-Aziz (PPP PG1532015A). The authors would like to acknowledge Professor 
Andrew J. Copp and Professor Nicholas D. E. Greene (University College London) for helpful discussions.

\section{References}

[1] K. M. Szymanski, R. Misseri, B. Whittam et al., "Quality of life assessment in spina bifida for children (QUALAS-C): development and validation of a novel health-related quality of life instrument," Urology, vol. 87, pp. 178-184, 2016.

[2] N. Fischer, P. Church, J. Lyons, and A. C. Mcpherson, "A qualitative exploration of the experiences of children with spina bifida and their parents around incontinence and social participation," Child: Care, Health and Development, vol. 41, no. 6, pp. 954-962, 2015.

[3] A. J. Copp, N. S. Adzick, L. S. Chitty, J. M. Fletcher, G. N. Holmbeck, and G. M. Shaw, "Spina bifida," Nature Reviews Disease Primers, vol. 1, article 15007, 2015.

[4] M. J. Harris and D. M. Juriloff, "An update to the list of mouse mutants with neural tube closure defects and advances toward a complete genetic perspective of neural tube closure," Birth Defects Research Part A: Clinical and Molecular Teratology, vol. 88, no. 8, pp. 653-669, 2010.

[5] D. M. Juriloff and M. J. Harris, "A consideration of the evidence that genetic defects in planar cell polarity contribute to the etiology of human neural tube defects," Birth Defects Research A-Clinical and Molecular Teratology, vol. 94, no. 10, pp. 824840, 2012.

[6] N. D. E. Greene, D. Gerrelli, H. W. M. Van Straaten, and A. J. Copp, "Abnormalities of floor plate, notochord and somite differentiation in the loop-tail (LP) mouse: a model of severe neural tube defects," Mechanisms of Development, vol. 73, no. 1, pp. 59-72, 1998.

[7] A. J. Copp and N. D. E. Greene, "Neural tube defects-disorders of neurulation and related embryonic processes," Wiley Interdisciplinary Reviews: Developmental Biology, vol. 2, no. 2, pp. 213-227, 2013.

[8] S. Abu-Abed, P. Dollé, D. Metzger, B. Beckett, P. Chambon, and M. Petkovich, "The retinoic acid-metabolizing enzyme, CYP26A1, is essential for normal hindbrain patterning, vertebral identity, and development of posterior structures," Genes and Development, vol. 15, no. 2, pp. 226-240, 2001.

[9] O. V. Bulgakov, J. T. Eggenschwiler, D.-H. Hong, K. V. Anderson, and $\mathrm{T}$. $\mathrm{Li}$, "FKBP8 is a negative regulator of mouse sonic hedgehog signaling in neural tissues," Development, vol. 131, no. 9, pp. 2149-2159, 2004.

[10] C. Chiang, Y. Litingtung, E. Lee et al., "Cyclopia and defective axial patterning in mice lacking Sonic hedgehog gene function," Nature, vol. 383, no. 6599, pp. 407-413, 1996.

[11] Q. Ding, J. Motoyama, S. Gasca et al., "Diminished Sonic hedgehog signaling and lack of floor plate differentiation in Gli2 mutant mice," Development, vol. 125, no. 14, pp. 2533-2543, 1998.

[12] R. Lawrenson, J.-J. Wyndaele, I. Vlachonikolis, C. Farmer, and S. Glickman, "A UK general practice database study of prevalence and mortality of people with neural tube defects," Clinical Rehabilitation, vol. 14, no. 6, pp. 627-630, 2000.

[13] S. E. Parker, C. T. Mai, M. A. Canfield et al., "Updated national birth prevalence estimates for selected birth defects in the United States, 2004-2006," Birth Defects Research Part A: Clinical and Molecular Teratology, vol. 88, no. 12, pp. 1008-1016, 2010.

[14] N.-Y. Boo, I. G. S. Cheah, and M.-K. Thong, "Neural tube defects in malaysia: data from the malaysian national neonatal registry,"
Journal of Tropical Pediatrics, vol. 59, no. 5, Article ID fmt026, pp. 338-342, 2013.

[15] L. Jin, L. Zhang, Z. Li, J.-M. Liu, R. Ye, and A. Ren, "Placental concentrations of mercury, lead, cadmium, and arsenic and the risk of neural tube defects in a Chinese population," Reproductive Toxicology, vol. 35, no. 1, pp. 25-31, 2013.

[16] Z. Wang, S. Shangguan, X. Lu et al., "Association of SMO polymorphisms and neural tube defects in the Chinese population from Shanxi Province," International Journal of Clinical and Experimental Medicine, vol. 6, no. 10, pp. 960-966, 2013.

[17] Z. Wang, L. Wang, S. Shangguan et al., "Association between PTCH1 polymorphisms and risk of neural tube defects in a Chinese population," Birth Defects Research Part A - Clinical and Molecular Teratology, vol. 97, no. 6, pp. 409-415, 2013.

[18] M. Wu, D. F. Chen, T. Sasaoka, and S. Tonegawa, "Neural tube defects and abnormal brain development in F52-deficient mice," Proceedings of the National Academy of Sciences of the United States of America, vol. 93, no. 5, pp. 2110-2115, 1996.

[19] S. O. Ekenze, O. V. Ajuzieogu, and B. C. Nwomeh, "Neonatal surgery in Africa: a systematic review and meta-analysis of challenges of management and outcome," The Lancet, vol. 385, supplement 2, p. S35, 2015.

[20] L. E. Mitchell, N. Scott Adzick, J. Melchionne, P. S. Pasquariello, L. N. Sutton, and A. S. Whitehead, "Spina bifida," Lancet, vol. 364, no. 9448, pp. 1885-1895, 2004.

[21] R. Masson, C. H. Régnier, M.-P. Chenard et al., “Tumor necrosis factor receptor associated factor 4 (TRAF4) expression pattern during mouse development," Mechanisms of Development, vol. 71, no. 1-2, pp. 187-191, 1998.

[22] A. H. Jobe, "Fetal surgery for myelomeningocele," The New England Journal of Medicine, vol. 347, no. 4, pp. 230-231, 2002.

[23] G. P. Giacoia and B. Say, "Spondylocostal dysplasia and neural tube defects," Journal of Medical Genetics, vol. 28, no. 1, pp. 5153, 1991.

[24] M. M. Rodriguez, A. Mejias Jr., R. L. Haun, M. B. Mata, and J. H. Bruce, "Spondylocostal dysostosis with perinatal death and meningomyelocele," Pediatric Pathology, vol. 14, no. 1, pp. 53-59, 1994.

[25] S. Duru, S. Ceylan, B. H. Güvenç, and S. Ceylan, "Segmental costovertebral malformations: association with neural tube defects. Report of 3 cases and review of the literature," Pediatric Neurosurgery, vol. 30, no. 5, pp. 272-277, 1999.

[26] E. Kauffmann, H. Roman, G. Barau et al., "Case report: a prenatal case of Jarcho-Levin syndrome diagnosed during the first trimester of pregnancy," Prenatal Diagnosis, vol. 23, no. 2, pp. 163-165, 2003.

[27] T. D. Nadkarni and H. L. Rekate, "Treatment of refractory intracranial hypertension in a spina bifida patient by a concurrent ventricular and cisterna magna-to-peritoneal shunt," Child's Nervous System, vol. 21, no. 7, pp. 579-582, 2005.

[28] S. Yi, D. H. Yoon, H. C. Shin, K. N. Kim, and S. W. Lee, "A thoracic myelomeningocele in a patient with spondylocostal dysostosis. Case report," Journal of Neurosurgery, vol. 104, no. 1, pp. 37-40, 2006.

[29] B. Dane, C. Dane, F. Aksoy, A. Cetin, and M. Yayla, "JarchoLevin syndrome presenting as neural tube defect: report of four cases and pitfalls of diagnosis," Fetal Diagnosis and Therapy, vol. 22, no. 6, pp. 416-419, 2007.

[30] J. L. Tolmie, M. J. Whittle, M. B. McNay, A. A. Gibson, and J. M. Connor, "Second trimester prenatal diagnosis of the JarchoLevin syndrome," Prenatal Diagnosis, vol. 7, no. 2, pp. 129-134, 1987. 
[31] R. Romero, A. Ghidini, M. S. Eswara, M. R. Seashore, and J. C. Hobbins, "Prenatal findings in a case of spondylocostal dysplasia type I (Jarcho-Levin syndrome)," Obstetrics and Gynecology, vol. 71, no. 6, pp. 988-991, 1988.

[32] R. C. M. Hennekam, F. A. Beemer, W. A. R. Huijbers, P. A. Hustinx, and F. J. van Sprang, "The cerebro-costo-mandibular syndrome: third report of familial occurrence," Clinical Genetics, vol. 28, no. 2, pp. 118-121, 1985.

[33] A. Amorosi, M. D’armiento, G. Calcagno et al., "FOXN1 homozygous mutation associated with anencephaly and severe neural tube defect in human athymic Nude/SCID fetus," Clinical Genetics, vol. 73, no. 4, pp. 380-384, 2008.

[34] N. Manjunath and C. S. Vijaya Sreenivas, "New manifestations of Neu-Laxova syndrome," American Journal of Medical Genetics, vol. 35, no. 1, pp. 55-59, 1990.

[35] M. E. Rode, M. T. Mennuti, R. M. Giardine, E. H. Zackai, and D. A. Driscoll, "Early ultrasound diagnosis of Neu-Laxova syndrome," Prenatal Diagnosis, vol. 21, no. 7, pp. 575-580, 2001.

[36] M. J. Seller, S. Mohammed, J. Russell, and C. Ogilvie, "Microdeletion 22q11.2, Kousseff syndrome and spina bifida," Clinical Dysmorphology, vol. 11, no. 2, pp. 113-115, 2002.

[37] S. Chatkupt, S. Chatkupt, and W. G. Johnson, "Waardenburg syndrome and myelomeningocele in a family," Journal of Medical Genetics, vol. 30, no. 1, pp. 83-84, 1993.

[38] J. S. Nye, N. Balkin, H. Lucas, P. A. Knepper, D. G. McLone, and J. Charrow, "Myelomeningocele and Waardenburg syndrome (type 3) in patients with interstitial deletions of 2q35 and the PAX3 gene: possible digenic inheritance of a neural tube defect," American Journal of Medical Genetics, vol. 75, no. 4, pp. 401-408, 1998.

[39] F. A. Hol, B. C. J. Hamel, M. P. A. Geurds et al., "A frameshift mutation in the gene for PAX3 in a girl with spina bifida and mild signs of Waardenburg syndrome," Journal of Medical Genetics, vol. 32, no. 1, pp. 52-56, 1995.

[40] S. H. Shim, H. E. Wyandt, D. M. McDonald-McGinn, E. Z. Zackai, and A. Milunsky, "Molecular cytogenetic characterization of multiple intrachromosomal rearrangements of chromosome $2 \mathrm{q}$ in a patient with Waardenburg's syndrome and other congenital defects," Clinical Genetics, vol. 66, no. 1, pp. 46$52,2004$.

[41] A. Kujat, V.-P. Veith, R. Faber, and U. G. Froster, "Prenatal diagnosis and genetic counseling in a case of spina bifida in a family with Waardenburg syndrome type I," Fetal Diagnosis and Therapy, vol. 22, no. 2, pp. 155-158, 2007.

[42] S. Chatkupt, J. H. Skurnick, M. Jaggi, K. Mitruka, M. R. Koenigsberger, and W. G. Johnson, "Study of genetics, epidemiology, and vitamin usage in familial spina bifida in the united states in the 1990s," Neurology, vol. 44, no. 1, pp. 65-70, 1994.

[43] P. A. Gardner and A. L. Albright, “"Like mother, like son:” hereditary anterior sacral meningocele-case report and review of the literature," Journal of Neurosurgery, vol. 104, no. 2, pp. 138142, 2006.

[44] Z. Kibar, E. Torban, J. R. McDearmid et al., "Mutations in VANGL1 associated with neural-tube defects," New England Journal of Medicine, vol. 356, no. 14, pp. 1432-1437, 2007.

[45] A. Czeizel and A. Losonci, "Split hand, obstructive urinary anomalies and spina bifida or diaphragmatic defect syndrome with autosomal dominant inheritance," Human Genetics, vol. 77, no. 2, pp. 203-204, 1987.

[46] L. Almeida, K. Anyane-Yeboa, M. Grossman, and T. Rosen, "Myelomeningocele, Arnold-Chiari anomaly and hydro- cephalus in focal dermal hypoplasia," American Journal of Medical Genetics, vol. 30, no. 4, pp. 917-923, 1988.

[47] R. S. Mathias, R. V. Lacro, and K. L. Jones, "X-linked laterality sequence: situs inversus, complex cardiac defects, splenic defects," American Journal of Medical Genetics, vol. 28, no. 1, pp. 111-116, 1987.

[48] M. Gebbia, G. B. Ferrero, G. Pilia et al., "X-linked situs abnormalities result from mutations in ZIC3," Nature Genetics, vol. 17, no. 3, pp. 305-308, 1997.

[49] C. Dane, B. Dane, M. Yayla, and A. Cetin, "Prenatal diagnosis of a case of pentalogy of Cantrell with spina bifida," Journal of Postgraduate Medicine, vol. 53, no. 2, pp. 146-148, 2007.

[50] K. Nudleman, E. Andermann, F. Andermann, G. Bertrand, and E. Rogala, "The HEMI 3 syndrome. Hemihypertrophy, hemihypaesthesia, hemiareflexia and scoliosis," Brain, vol. 107, no. 2, pp. 533-546, 1984.

[51] R. Sharony, S. H. Pepkowitz, H. Hixon, G. A. Machin, and J. M. Graham Jr., "Diprosopus: a pregastrulation defect involving the head, neural tube, heart, and diaphragm," Birth Defects: Original Article Series, vol. 29, no. 1, pp. 201-209, 1993.

[52] R. J. Terrafranca and A. Zellis, "Congenital hereditary cranium bifidum occultum frontalis with a review of anatomical variations in lower medsagittal region of frontal bones," Radiology, vol. 61, no. 1, pp. 60-66, 1953.

[53] I. H. Tekkök, "Triple neural tube defect-cranium bifidum with rostral and caudal spina bifida-live evidence of multi-site closure of the neural tube in humans," Child's Nervous System, vol. 21, no. 4, pp. 331-335, 2005.

[54] M. J. Harris and D. M. Juriloff, "Mouse mutants with neural tube closure defects and their role in understanding human neural tube defects," Birth Defects Research A-Clinical and Molecular Teratology, vol. 79, no. 3, pp. 187-210, 2007.

[55] B. Franke, S. H. H. M. Vermeulen, R. P. M. Steegers-Theunissen et al., "An association study of 45 folate-related genes in spina bifida: involvement of Cubilin (CUBN) and tRNA Aspartic Acid Methyltransferase 1 (TRDMT1)," Birth Defects Research A-Clinical and Molecular Teratology, vol. 85, no. 3, pp. 216-226, 2009.

[56] G. M. Shaw, W. Lu, H. Zhu et al., "118 SNPs of folate-related genes and risks of spina bifida and conotruncal heart defects," BMC Medical Genetics, vol. 10, article 49, 2009.

[57] H. Zhu, S. Curry, S. Wen et al., "Are the betaine-homocysteine methyltransferase (BHMT and BHMT2) genes risk factors for spina bifida and orofacial clefts?" American Journal of Medical Genetics A, vol. 135, no. 3, pp. 274-277, 2005.

[58] J. O. Ebot Enaw, H. Zhu, W. Yang et al., "CHKA and PCYT1A gene polymorphisms, choline intake and spina bifida risk in a California population," BMC Medicine, vol. 4, article no. 36, 2006.

[59] K. Doudney, J. Grinham, J. Whittaker et al., "Evaluation of folate metabolism gene polymorphisms as risk factors for open and closed neural tube defects," American Journal of Medical Genetics, Part A, vol. 149, no. 7, pp. 1585-1589, 2009.

[60] V. B. O’Leary, J. L. Mills, A. Parle-McDermott et al., "Screening for new MTHFR polymorphisms and NTD risk," American Journal of Medical Genetics Part A, vol. 138, no. 2, pp. 99-106, 2005.

[61] I. J. M. Van Der Linden, M. Den Heijer, L. A. Afman et al., "The methionine synthase reductase $66 \mathrm{~A}>\mathrm{G}$ polymorphism is a maternal risk factor for spina bifida," Journal of Molecular Medicine, vol. 84, no. 12, pp. 1047-1054, 2006. 
[62] I. J. M. Van Der Linden, S. G. Heil, M. Den Heijer, and H. J. Blom, "The $894 \mathrm{G}>\mathrm{T}$ variant in the endothelial nitric oxide synthase gene and spina bifida risk," Journal of Human Genetics, vol. 52, no. 6, pp. 516-520, 2007.

[63] K. S. Brown, M. Cook, K. Hoess, A. S. Whitehead, and L. E. Mitchell, "Evidence that the risk of spina bifida is influenced by genetic variation at the NOS3 locus," Birth Defects Research Part A: Clinical and Molecular Teratology, vol. 70, no. 3, pp. 101-106, 2004.

[64] T. M. King, K.-S. Au, T. J. Kirkpatrick et al., "The impact of BRCA1 on spina bifida meningomyelocele lesion," Annals of Human Genetics, vol. 71, no. 6, pp. 719-728, 2007.

[65] H. Zhu, J. O. E. Enaw, C. Ma, G. M. Shaw, E. J. Lammer, and R. H. Finnell, "Association between CFL1 gene polymorphisms and spina bifida risk in a California population," BMC Medical Genetics, vol. 8, article 12, 2007.

[66] W. Lu, H. Zhu, S. Wen et al., "Screening for novel PAX3 polymorphisms and risks of spina bifida," Birth Defects Research Part A-Clinical and Molecular Teratology, vol. 79, no. 1, pp. 4549, 2007.

[67] M. Toepoel, R. P. M. Steegers-Theunissen, N. J. Ouborg et al., "Interaction of PDGFRA promoter haplotypes and maternal environmental exposures in the risk of spina bifida," Birth Defects Research Part A - Clinical and Molecular Teratology, vol. 85, no. 7, pp. 629-636, 2009.

[68] K.-S. Au, H. Northrup, T. J. Kirkpatrick et al., "Promotor genotype of the platelet-derived growth factor receptor- $\alpha$ gene shows population stratification but not association with spina bifida meningomyelocele," American Journal of Medical Genetics Part A, vol. 139, no. 3, pp. 194-198, 2005.

[69] S. Wen, W. Lu, H. Zhu et al., "Genetic polymorphisms in the thioredoxin 2 (TXN2) gene and risk for spina bifida," American Journal of Medical Genetics A, vol. 149, no. 2, pp. 155-160, 2009.

[70] R. Klootwijk, P. Groenen, M. Schijvenaars et al., "Genetic variants in ZIC1, ZIC2, and ZIC3 are not major risk factors for neural tube defects in humans," American Journal of Medical Genetics, vol. 124, no. 1, pp. 40-47, 2004.

[71] I. J. M. van der Linden, U. Nguyen, S. G. Heil et al., "Variation and expression of dihydrofolate reductase (DHFR) in relation to spina bifida," Molecular Genetics and Metabolism, vol. 91, no. 1, pp. 98-103, 2007.

[72] A. Parle-McDermott, F. Pangilinan, J. L. Mills et al., "The 19-bp deletion polymorphism in intron-1 of dihydrofolate reductase (DHFR) May decrease rather than increase risk for spina bifida in the Irish population," American Journal of Medical Genetics, Part A, vol. 143, no. 11, pp. 1174-1180, 2007.

[73] W. G. Johnson, E. S. Stenroos, J. R. Spychala, S. Chatkupt, S. X. Ming, and S. Buyske, "New 19 bp deletion polymorphism in intron-1 of dihydrofolate reductase (DHFR): a risk factor for spina bifida acting in mothers during pregnancy?" American Journal of Medical Genetics Part A, vol. 124, no. 4, pp. 339-345, 2004.

[74] N. Carroll, F. Pangilinan, A. M. Molloy et al., "Analysis of the MTHFD1 promoter and risk of neural tube defects," Human Genetics, vol. 125, no. 3, pp. 247-256, 2009.

[75] P. De Marco, E. Merello, M. G. Calevo et al., "Evaluation of a methylenetetrahydrofolate-dehydrogenase $1958 \mathrm{G}>$ A polymorphism for neural tube defect risk," Journal of Human Genetics, vol. 51, no. 2, pp. 98-103, 2006.

[76] A. Parle-McDermott, P. N. Kirke, J. L. Mills et al., "Confirmation of the R653Q polymorphism of the trifunctional C1-synthase enzyme as a maternal risk for neural tube defects in the Irish population," European Journal of Human Genetics, vol. 14, no. 6, pp. 768-772, 2006.

[77] E. Grandone, A. M. Corrao, D. Colaizzo et al., "Homocysteine metabolism in families from southern Italy with neural tube defects: role of genetic and nutritional determinants," Prenatal Diagnosis, vol. 26, no. 1, pp. 1-5, 2006.

[78] L. Gonzalez-Herrera, I. Castillo-Zapata, G. Garcia-Escalante, and D. Pinto-Escalante, "A1298C polymorphism of the MTHFR gene and neural tube defects in the state of Yucatan, Mexico," Birth Defects Research Part A: Clinical and Molecular Teratology, vol. 79, no. 8, pp. 622-626, 2007.

[79] K. A. Volcik, G. M. Shaw, H. Zhu, E. J. Lammer, C. Laurent, and R. H. Finnell, "Associations between polymorphisms within the thymidylate synthase gene and spina bifida," Birth Defects Research Part A: Clinical and Molecular Teratology, vol. 67, no. 11, pp. 924-928, 2003.

[80] C. M. Davidson, H. Northrup, T. M. King et al., "Genes in glucose metabolism and association with spina bifida," Reproductive Sciences, vol. 15, no. 1, pp. 51-58, 2008.

[81] A. F. Olshan, G. M. Shaw, R. C. Millikan, C. Laurent, and R. H. Finnell, "Polymorphisms in DNA repair genes as risk factors for spina bifida and orofacial clefts," American Journal of Medical Genetics, vol. 135, no. 3, pp. 268-273, 2005.

[82] K. Doudney, G. E. Moore, P. Stanier et al., "Analysis of the planar cell polarity gene Vangl2 and its co-expressed paralogue Vangll in neural tube defect patients," American Journal of Medical Genetics, vol. 136, no. 1, pp. 90-92, 2005.

[83] Z. Kibar, C. M. Bosoi, M. Kooistra et al., "Novel mutations in VANGL1 in neural tube defects," Human Mutation, vol. 30, no. 7, pp. E706-E715, 2009.

[84] Y. Lei, H. Zhu, W. Yang, M. E. Ross, G. M. Shaw, and R. H. Finnell, "Identification of novel CELSR1 mutations in spina bifida," PLoS ONE, vol. 9, no. 3, Article ID e92207, 2014.

[85] Y. Lei, H. Zhu, C. Duhon et al., "Mutations in planar cell polarity gene SCRIB are associated with spina bifida," PLOS ONE, vol. 8, no. 7, Article ID e69262, 2013.

[86] S. Chen, Q. Zhang, B. Bai et al., "MARK2/Parlb insufficiency attenuates $D V L$ gene transcription via histone deacetylation in lumbosacral spina bifida," Molecular Neurobiology, 2016.

[87] K. L. Deak, M. E. Dickerson, E. Linney et al., "Analysis of ALDH1A2, CYP26A1, CYP26B1, CRABP1, and CRABP2 in human neural tube defects suggests a possible association with alleles in ALDH1A2," Birth Defects Research A-Clinical and Molecular Teratology, vol. 73, no. 11, pp. 868-875, 2005.

[88] L. E. Jensen, S. Barbaux, K. Hoess, S. Fraterman, A. S. Whitehead, and L. E. Mitchell, "The human T locus and spina bifida risk," Human Genetics, vol. 115, no. 6, pp. 475-482, 2004.

[89] H. Zhu, W. Yang, W. Lu et al., "A known functional polymorphism (Ile120Val) of the human PCMT1 gene and risk of spina bifida," Molecular Genetics and Metabolism, vol. 87, no. 1, pp. 6670, 2006.

[90] B. A. Kase, H. Northrup, A. C. Morrison et al., "Association of copper-zinc superoxide dismutase (SOD1) and manganese superoxide dismutase (SOD2) genes with nonsyndromic myelomeningocele," Birth Defects Research Part A: Clinical and Molecular Teratology, vol. 94, no. 10, pp. 762-769, 2012.

[91] A. Robinson, D. Partridge, A. Malhas et al., "Is LMNB1 a susceptibility gene for neural tube defects in humans?" Birth Defects Research A-Clinical and Molecular Teratology, vol. 97, no. 6, pp. 398-402, 2013. 
[92] K. L. Deak, A. L. Boyles, H. C. Etchevers et al., "SNPs in the neural cell adhesion molecule 1 gene (NCAM1) may be associated with human neural tube defects," Human Genetics, vol. 117, no. 2-3, pp. 133-142, 2005.

[93] N. D. E. Greene, P. Stanier, and A. J. Copp, "Genetics of human neural tube defects," Human Molecular Genetics, vol. 18, no. 2, pp. R113-R129, 2009.

[94] C. Deng, M. Bedford, C. Li et al., "Fibroblast growth factor receptor-1 (FGFR-1) is essential for normal neural tube and limb development," Developmental Biology, vol. 185, no. 1, pp. 42-54, 1997.

[95] C. H. Régnier, R. Masson, V. Kedinger et al., "Impaired neural tube closure, axial skeleton malformations, and tracheal ring disruption in TRAF4-deficient mice," Proceedings of the National Academy of Sciences of the United States of America, vol. 99, no. 8, pp. 5585-5590, 2002.

[96] T. M. Saxton and T. Pawson, "Morphogenetic movements at gastrulation require the $\mathrm{SH} 2$ tyrosine phosphatase Shp2," Proceedings of the National Academy of Sciences of the United States of America, vol. 96, no. 7, pp. 3790-3795, 1999.

[97] F. B. Essien, M. B. Haviland, and A. E. Naidoff, "Expression of a new mutation (Axd) causing axial defects in mice correlates with maternal phenotype and age," Teratology, vol. 42, no. 2, pp. 183-194, 1990.

[98] B. Nait-Oumesmar, B. Stecca, G. Fatterpekar, T. Naidich, J. Corbin, and R. A. Lazzarini, "Ectopic expression of $\mathrm{Gcml}$ induces congenital spinal cord abnormalities," Development, vol. 129, no. 16, pp. 3957-3964, 2002.

[99] D. B. Wilson and D. P. Wyatt, "Pathogenesis of neural dysraphism in the mouse mutant vacuolated lens (vl)," Journal of Neuropathology and Experimental Neurology, vol. 45, no. 1, pp. 43-55, 1986.

[100] J. Qu, X. Li, B. G. Novitch et al., "PAK4 kinase is essential for embryonic viability and for proper neuronal development," Molecular and Cellular Biology, vol. 23, no. 20, pp. 7122-7133, 2003.

[101] C. Naruse-Nakajima, M. Asano, and Y. Iwakura, "Involvement of EphA2 in the formation of the tail notochord via interaction with ephrinA1," Mechanisms of Development, vol. 102, no. 1-2, pp. 95-105, 2001.

[102] S. B. Snapper, F. Takeshima, I. Antón et al., "N-WASP deficiency reveals distinct pathways for cell surface projections and microbial actin-based motility," Nature Cell Biology, vol. 3, no. 10, pp. 897-904, 2001.

[103] W. Xu, H. Baribault, and E. D. Adamson, "Vinculin knockout results in heart and brain defects during embryonic development," Development, vol. 125, no. 2, pp. 327-337, 1998.

[104] P. Elms, P. Siggers, D. Napper, A. Greenfield, and R. Arkell, "Zic2 is required for neural crest formation and hindbrain patterning during mouse development," Developmental Biology, vol. 264, no. 2, pp. 391-406, 2003.

[105] Z. Kibar, K. J. Vogan, N. Groulx, M. J. Justice, D. A. Underhill, and P. Gros, "Ltap, a mammalian homolog of Drosophila Strabismus/Van Gogh, is altered in the mouse neural tube mutant Loop-tail," Nature Genetics, vol. 28, no. 3, pp. 251-255, 2001.

[106] S.-L. Ang and J. Rossant, "HNF-3 $\beta$ is essential for node and notochord formation in mouse development," Cell, vol. 78, no. 4, pp. 561-574, 1994.

[107] K. Doudney and P. Stanier, "Epithelial cell polarity genes are required for neural tube closure," American Journal of Medical
Genetics - Seminars in Medical Genetics, vol. 135, no. 1, pp. 42-47, 2005.

[108] J. Galceran, I. Fariñas, M. J. Depew, H. Clevers, and R. Grosschedl, "Wnt $3 a^{-1-}$-like phenotype and limb deficiency in Lef1 $^{-/-} \mathrm{Tcfl}^{-/-}$mice," Genes and Development, vol. 13, no. 6, pp. 709-717, 1999.

[109] S. Abu-Abed, P. Dollé, D. Metzger et al., "Developing with lethal RA levels: genetic ablation of Rarg can restore the viability of mice lacking Cyp26al," Development, vol. 130, no. 7, pp. 14491459, 2003.

[110] H. Chi, M. R. Sarkisian, P. Rakic, and R. A. Flavell, "Loss of mitogen-activated protein kinase kinase kinase 4 (MEKK4) results in enhanced apoptosis and defective neural tube development," Proceedings of the National Academy of Sciences of the United States of America, vol. 102, no. 10, pp. 3846-3851, 2005.

[111] J. Chen, S. Chang, S. A. Duncan, H. J. Okano, G. Fishell, and A. Aderem, "Disruption of the MacMARCKS gene prevents cranial neural tube closure and results in anencephaly," Proceedings of the National Academy of Sciences of the United States of America, vol. 93, no. 13, pp. 6275-6279, 1996.

[112] M. J. Solloway and E. J. Robertson, "Early embryonic lethality in Bmp5;Bmp7 double mutant mice suggests functional redundancy within the 60A subgroup," Development, vol. 126, no. 8 , pp. 1753-1768, 1999.

[113] E. Martí, R. Takada, D. A. Bumcrot, H. Sasaki, and A. P. McMahon, "Distribution of Sonic hedgehog peptides in the developing chick and mouse embryo," Development, vol. 121, no. 8, pp. 2537-2547, 1995.

[114] D. C. Weinstein, A. Ruiz i Altaba, W. S. Chen et al., "The wingedhelix transcription factor HNF-3 $\beta$ is required for notochord development in the mouse embryo," Cell, vol. 78, no. 4, pp. 575$588,1994$.

[115] J. Dubrulle and O. Pourquié, "fgf8 mRNA decay establishes a gradient that couples axial elongation to patterning in the vertebrate embryo," Nature, vol. 427, no. 6973, pp. 419-422, 2004.

[116] A. Auden, J. Caddy, T. Wilanowski, S. B. Ting, J. M. Cunningham, and S. M. Jane, "Spatial and temporal expression of the Grainyhead-like transcription factor family during murine development," Gene Expression Patterns, vol. 6, no. 8, pp. 964970, 2006.

[117] E.-H. Jho, T. Zhang, C. Domon, C.-K. Joo, J.-N. Freund, and F. Costantini, "Wnt/ $\beta$-catenin/Tcf signaling induces the transcription of Axin2, a negative regulator of the signaling pathway," Molecular and Cellular Biology, vol. 22, no. 4, pp. 1172$1183,2002$.

[118] M. D. Goulding, G. Chalepakis, U. Deutsch, J. R. Erselius, and P. Gruss, "Pax-3, a novel murine DNA binding protein expressed during early neurogenesis," EMBO Journal, vol. 10, no. 5, pp. $1135-1147,1991$.

[119] C. Ramos and B. Robert, "msh/Msx gene family in neural development," Trends in Genetics, vol. 21, no. 11, pp. 624-632, 2005.

[120] E. Camerer, A. Barker, D. N. Duong et al., "Local protease signaling contributes to neural tube closure in the mouse embryo," Developmental Cell, vol. 18, no. 1, pp. 25-38, 2010.

[121] N. M. J. Van Der Put, H. W. M. Van Straaten, F. J. M. Trijbels, and H. J. Blom, "Folate, homocysteine and neural tube defects: an overview," Experimental Biology and Medicine, vol. 226, no. 4, pp. 243-270, 2001. 
[122] P. Tortori-Donati, A. Rossi, and A. Cama, "Spinal dysraphism: a review of neuroradiological features with embryological correlations and proposal for a new classification," Neuroradiology, vol. 42, no. 7, pp. 471-491, 2000.

[123] J. J. Volpe, Neurology of the Newborn, Saunders, Philadelphia, $\mathrm{Pa}$, USA, 1995.

[124] K. L. Stevenson, "Chiari type II malformation: past, present, and future," Neurosurgical focus, vol. 16, no. 2, article E5, 2004.

[125] H. Williams, "A unifying hypothesis for hydrocephalus, Chiari malformation, syringomyelia, anencephaly and spina bifida," Cerebrospinal Fluid Research, vol. 5, article 7, 2008.

[126] B. G. Coleman, N. S. Adzick, T. M. Crombleholme et al., "Fetal therapy: state of the art," Journal of Ultrasound in Medicine, vol. 21, no. 11, pp. 1257-1288, 2002.

[127] N. S. Adzick, L. N. Sutton, T. M. Crombleholme, and A. W. Flake, "Successful fetal surgery for spina bifida," Lancet, vol. 352, no. 9141, pp. 1675-1676, 1998.

[128] N. S. Adzick, E. A. Thom, C. Y. Spong et al., "A randomized trial of prenatal versus postnatal repair of myelomeningocele," New England Journal of Medicine, vol. 364, no. 11, pp. 993-1004, 2011.

[129] J. D. Eubanks and V. K. Cheruvu, "Prevalence of sacral spina bifida occulta and its relationship to age, sex, race, and the sacral table angle: an anatomic, osteologic study of three thousand one hundred specimens," Spine, vol. 34, no. 15, pp. 1539-1543, 2009.

[130] A. Fidas, H. L. MacDonald, R. A. Elton, S. R. Wild, G. D. Chisholm, and R. Scott, "Prevalence and patterns of spina bifida occulta in 2707 normal adults," Clinical Radiology, vol. 38, no. 5, pp. 537-542, 1987.

[131] L. May, R. Hayward, A. Chakraborty et al., "Lack of uniformity in the clinical assessment of children with lipomyelomeningocele: a review of the literature and recommendations for the future," Child's Nervous System, vol. 29, no. 6, pp. 961-970, 2013.

[132] N. K. Venkataramana, "Spinal dysraphism," Journal of Pediatric Neurosciences, vol. 6, no. 3, pp. S31-S40, 2011.

[133] B. J. Iskandar, B. B. Fulmer, M. N. Hadley, and W. J. Oakes, "Congenital tethered spinal cord syndrome in adults," Journal of Neurosurgery, vol. 88, no. 6, pp. 958-961, 1998.

[134] J. Lorber, "Selective treatment of myelomeningocele: to treat or not to treat?" Pediatrics, vol. 53, no. 3, pp. 307-308, 1974.

[135] J. P. Bruner and N. Tulipan, "Intrauterine repair of spina bifida," Clinical Obstetrics and Gynecology, vol. 48, no. 4, pp. 942-955, 2005.

[136] J. H. Piatt Jr., "Treatment of myelomeningocele: a review of outcomes and continuing neurosurgical considerations among adults-a review," Journal of Neurosurgery: Pediatrics, vol. 6, no. 6, pp. 515-525, 2010.

[137] R. M. Bowman, D. G. McLone, J. A. Grant, T. Tomita, and J. A. Ito, "Spina bifida outcome: a 25 -year prospective," Pediatric Neurosurgery, vol. 34, no. 3, pp. 114-120, 2001.

[138] R. Lawrenson, J.-J. Wyndaele, I. Vlachonikolis, C. Farmer, and S. Glickman, "Renal failure in patients with neurogenic lower urinary tract dysfunction," Neuroepidemiology, vol. 20, no. 2, pp. 138-143, 2001.

[139] H. T. Ireys, G. F. Anderson, T. J. Shaffer, and J. M. Neff, "Expenditures for care of children with chronic illnesses enrolled in the Washington State Medicaid Program, fiscal year 1993," Pediatrics, vol. 100, no. 2, pp. 197-204, 1997.

[140] M. M. Macias, K. M. Roberts, C. F. Saylor, and J. J. Fussell, "Toileting concerns, parenting stress, and behavior problems in children with special health care needs," Clinical Pediatrics, vol. 45, no. 5, pp. 415-422, 2006.
[141] M. Verhoef, H. A. Barf, M. W. M. Post, F. W. A. van Asbeck, R. H. J. M. Gooskens, and A. J. H. Prevo, "Functional independence among young adults with spina bifida, in relation to hydrocephalus and level of lesion," Developmental Medicine and Child Neurology, vol. 48, no. 2, pp. 114-119, 2006.

[142] A. H. Sin, M. Rashidi, G. Caldito, and A. Nanda, "Surgical treatment of myelomeningocele: year 2000 hospitalization, outcome, and cost analysis in the US," Child's Nervous System, vol. 23, no. 10, pp. 1125-1127, 2007.

[143] C.-P. Chen, "Syndromes, disorders and maternal risk factors associated with neural tube defects (I)," Taiwanese Journal of Obstetrics and Gynecology, vol. 47, no. 1, pp. 1-9, 2008.

[144] J. Hall and F. Solehdin, "Folic acid for the prevention of congenital anomalies," European Journal of Pediatrics, vol. 157, no. 6, pp. 445-450, 1998.

[145] L. H. Seaver and R. E. Stevenson, "Syndromes with neural tube defects," in Neural Tube Defects: From Origin to Treatment, D. F. Wyszynski, Ed., Oxford University Press, Oxford, UK, 2006.

[146] M. Z. Seidahmed, O. B. Abdelbasit, M. M. Shaheed et al., "Epidemiology of neural tube defects," Saudi Medical Journal, vol. 35, supplement 1, pp. S29-S35, 2014.

[147] L. B. Holmes, S. G. Driscoll, and L. Atkins, "Etiologic heterogeneity of neural-tube defects," New England Journal of Medicine, vol. 294, no. 7, pp. 365-369, 1976.

[148] M. J. Khoury, J. D. Erickson, and L. M. James, "Etiologic heterogeneity of neural tube defects: clues from epidemiology," American Journal of Epidemiology, vol. 115, no. 4, pp. 538-548, 1982.

[149] M. J. Khoury, J. David Erickson, and L. M. James, "Etiologic heterogeneity of neural tube defects. II. Clues from family studies," American Journal of Human Genetics, vol. 34, no. 6, pp. 980-987, 1982.

[150] R. A. Martin, R. M. Fineman, and L. B. Jorde, "Phenotypic heterogeneity in neural tube defects: a clue to causal heterogeneity," American Journal of Medical Genetics, vol. 16, no. 4, pp. 519-525, 1983.

[151] E. Rampersaud, E. C. Melvin, and M. C. Speer, Neural Tube Defects: From Origin to Treatment, Oxford University Press, 2006.

[152] M. J. Aguiar, A. S. Campos, R. A. Aguiar, A. M. Lana, R. L. Magalhaes, and L. T. Babeto, "Neural tube defects and associated factors in liveborn and stillborn infants," Jornal de Pediatria (Rio de Janeiro), vol. 79, no. 2, pp. 129-134, 2003.

[153] J. Dietl, "Maternal obesity and complications during pregnancy," Journal of Perinatal Medicine, vol. 33, no. 2, pp. 100-105, 2005.

[154] L. F. Hall and A. G. Neubert, "Obesity and pregnancy," Obstetrical and Gynecological Survey, vol. 60, no. 4, pp. 253-260, 2005.

[155] R. Mojtabai, "Body mass index and serum folate in childbearing age women," European Journal of Epidemiology, vol. 19, no. 11, pp. 1029-1036, 2004.

[156] K. R. Andreasen, M. L. Andersen, and A. L. Schantz, "Obesity and pregnancy," Acta Obstetricia et Gynecologica Scandinavica, vol. 83, no. 11, pp. 1022-1029, 2004.

[157] D. K. Waller, J. L. Mills, J. L. Simpson et al., "Are obese women at higher risk for producing malformed offspring?" American Journal of Obstetrics and Gynecology, vol. 170, no. 2, pp. 541-548, 1994.

[158] S. A. Rasmussen, S. Y. Chu, S. Y. Kim, C. H. Schmid, and J. Lau, "Maternal obesity and risk of neural tube defects: a 
metaanalysis," American Journal of Obstetrics and Gynecology, vol. 198, no. 6, pp. 611-619, 2008.

[159] L. E. Jensen, K. Hoess, A. S. Whitehead, and L. E. Mitchell, "The NAT1 C1095A polymorphism, maternal multivitamin use and smoking, and the risk of spina bifida," Birth Defects Research Part A: Clinical and Molecular Teratology, vol. 73, no. 7, pp. 512516, 2005.

[160] L. Suarez, T. Ramadhani, M. Felkner et al., "Maternal smoking, passive tobacco smoke, and neural tube defects," Birth Defects Research Part A - Clinical and Molecular Teratology, vol. 91, no. 1, pp. 29-33, 2011.

[161] L. Wang, L. Jin, J. Liu et al., "Maternal genetic polymorphisms of phase II metabolic enzymes and the risk of fetal neural tube defects," Birth Defects Research Part A: Clinical and Molecular Teratology, vol. 100, no. 1, pp. 13-21, 2014.

[162] A. Ornoy, "Neuroteratogens in man: an overview with special emphasis on the teratogenicity of antiepileptic drugs in pregnancy," Reproductive Toxicology, vol. 22, no. 2, pp. 214-226, 2006.

[163] M. S. Yerby, "Management issues for women with epilepsy: neural tube defects and folic acid supplementation," Neurology, vol. 61, no. 6, pp. S23-S26, 2003.

[164] M. M. Werler, K. A. Ahrens, J. L. F. Bosco et al., "Use of antiepileptic medications in pregnancy in relation to risks of birth defects," Annals of Epidemiology, vol. 21, no. 11, pp. 842850, 2011.

[165] E. L. Fine, M. Horal, T. I. Chang, G. Fortin, and M. R. Loeken, "Evidence that elevated glucose causes altered gene expression, apoptosis, and neural tube defects in a mouse model of diabetic pregnancy," Diabetes, vol. 48, no. 12, pp. 2454-2462, 1999.

[166] L. Pani, M. Horal, and M. R. Loeken, "Polymorphic susceptibility to the molecular causes of neural tube defects during diabetic embryopathy," Diabetes, vol. 51, no. 9, pp. 2871-2874, 2002.

[167] M. E. Moretti, B. Bar-Oz, S. Fried, and G. Koren, "Maternal hyperthermia and the risk for neural tube defects in offspring: systematic review and meta-analysis," Epidemiology, vol. 16, no. 2, pp. 216-219, 2005.

[168] B.-F. Hwang, P. Magnus, and J. J. K. Jaakkola, "Risk of specific birth defects in relation to chlorination and the amount of natural organic matter in the water supply," American Journal of Epidemiology, vol. 156, no. 4, pp. 374-382, 2002.

[169] F. Bove, Y. Shim, and P. Zeitz, "Drinking water contaminants and adverse pregnancy outcomes: a review," Environmental Health Perspectives, vol. 110, supplement 1, pp. 61-74, 2002.

[170] C. G. Graves, G. M. Matanoski, and R. G. Tardiff, "Weight of evidence for an association between adverse reproductive and developmental effects and exposure to disinfection byproducts: a critical review," Regulatory Toxicology and Pharmacology, vol. 34, no. 2, pp. 103-124, 2001.

[171] P. Cavalli and A. J. Copp, "Inositol and folate resistant neural tube defects," Journal of medical genetics, vol. 39, no. 2, p. E5, 2002.

[172] G. M. Shaw, T. Quach, V. Nelson et al., "Neural tube defects associated with maternal periconceptional dietary intake of simple sugars and glycemic index," The American Journal of Clinical Nutrition, vol. 78, no. 5, pp. 972-978, 2003.

[173] C. Ulman, F. Taneli, F. Oksel, and H. Hakerlerler, "Zinc-deficient sprouting blight potatoes and their possible relation with neural tube defects," Cell Biochemistry and Function, vol. 23, no. 1, pp. 69-72, 2005.
[174] I. Martín, M. J. Gibert, C. Pintos, A. Noguera, A. Besalduch, and A. Obrador, "Oxidative stress in mothers who have conceived fetus with neural tube defects: the role of aminothiols and selenium," Clinical Nutrition, vol. 23, no. 4, pp. 507-514, 2004.

[175] P. M. W. Groenen, I. A. L. M. Van Rooij, P. G. M. Peer, R. H. Gooskens, G. A. Zielhuis, and R. P. M. Steegers-Theunissen, "Marginal maternal vitamin B 12 status increases the risk of offspring with spina bifida," American Journal of Obstetrics and Gynecology, vol. 191, no. 1, pp. 11-17, 2004.

[176] B. Cengiz, F. Söylemez, E. Öztürk, and A. O. Çavdar, "Serum zinc, selenium, copper, and lead levels in women with secondtrimester induced abortion resulting from neural tube defects: a preliminary study," Biological Trace Element Research, vol. 97, no. 3, pp. 225-235, 2004.

[177] J. P. Harmon, A. K. Hiett, C. G. Palmer, and A. M. Golichowski, "Prenatal ultrasound detection of isolated neural tube defects: is cytogenetic evaluation warranted?" Obstetrics and Gynecology, vol. 86, no. 4, pp. 595-599, 1995.

[178] R. F. Hume Jr., A. Drugan, A. Reichler et al., "Aneuploidy among prenatally detected neural tube defects," American Journal of Medical Genetics, vol. 61, no. 2, pp. 171-173, 1996.

[179] W. Coerdt, K. Miller, W. Holzgreve, R. Rauskolb, E. Schwinger, and H. Rehder, "Neural tube defects in chromosomally normal and abnormal human embryos," Ultrasound in Obstetrics and Gynecology, vol. 10, no. 6, pp. 410-415, 1997.

[180] J. S. Dashe, D. M. Twickler, R. Santos-Ramos, D. D. McIntire, and R. M. Ramus, "Alpha-fetoprotein detection of neural tube defects and the impact of standard ultrasound," American Journal of Obstetrics and Gynecology, vol. 195, no. 6, pp. 16231628, 2006.

[181] N. Wald and A. Hackshaw, "Folic acid and prevention of neuraltube defects," The Lancet, vol. 350, no. 9078, article no. 665, 1997.

[182] Z. Alfirevic, "DISQ 3: failure to diagnose a fetal anomaly on a routine ultrasound scan at 20 weeks," Ultrasound in Obstetrics and Gynecology, vol. 26, no. 7, pp. 797-798, 2005.

[183] E. Garne, M. Loane, H. Dolk et al., "Prenatal diagnosis of severe structural congenital malformations in Europe," Ultrasound in Obstetrics and Gynecology, vol. 25, no. 1, pp. 6-11, 2005.

[184] MRC Vitamin Study Research Group, "Prevention of neural tube defects: results of the Medical Research Council Vitamin Study," The Lancet, vol. 338, no. 8760, pp. 131-137, 1991.

[185] A. E. Czeizel and I. Dudás, "Prevention of the first occurrence of neural-tube defects by periconceptional vitamin supplementation," The New England Journal of Medicine, vol. 327, no. 26, pp. 1832-1835, 1992.

[186] N. D. E. Greene and A. J. Copp, "Inositol prevents folateresistant neural tube defects in the mouse," Nature Medicine, vol. 3, no. 1, pp. 60-66, 1997.

[187] N. D. Greene, K. Y. Leung, V. Gay et al., "Inositol for the prevention of neural tube defects: a pilot randomised controlled trial," British Journal of Nutrition, vol. 115, pp. 974-983, 2016.

[188] S. Bolusani, B. A. Young, N. A. Cole et al., "Mammalian MTHFD2L encodes a mitochondrial methylenetetrahydrofolate dehydrogenase isozyme expressed in adult tissues," Journal of Biological Chemistry, vol. 286, no. 7, pp. 5166-5174, 2011.

[189] J. Momb, J. P. Lewandowski, J. D. Bryant et al., "Deletion of Mthfdll causes embryonic lethality and neural tube and craniofacial defects in mice," Proceedings of the National Academy of Sciences of the United States of America, vol. 110, no. 2, pp. 549$554,2013$. 
[190] Y. J. Pai, K.-Y. Leung, D. Savery et al., "Glycine decarboxylase deficiency causes neural tube defects and features of nonketotic hyperglycinemia in mice," Nature Communications, vol. 6, article no. 6388, 2015.

[191] R. L. Agag, M. S. Granick, M. Omidi et al., "Neurosurgical reconstruction with acellular cadaveric dermal matrix," Annals of Plastic Surgery, vol. 52, no. 6, pp. 571-577, 2004.

[192] M. Watanabe, H. Li, A. G. Kim et al., "Complete tissue coverage achieved by scaffold-based tissue engineering in the fetal sheep model of Myelomeningocele," Biomaterials, vol. 76, pp. 133-143, 2016.

[193] Z. Kmietowicz, "Plymouth mother is first UK woman to have prenatal repair of open spina bifida funded by NHS," British Medical Journal, vol. 349, Article ID g6875, 2014.

[194] D. Stiefel, A. J. Copp, and M. Meuli, "Fetal spina bifida in a mouse model: loss of neural function in utero," Journal of Neurosurgery, vol. 106, no. 3, pp. 213-221, 2007.

[195] M. Meuli, C. Meuli-Simmen, C. D. Yingling et al., "Creation of myelomeningocele in utero: a model of functional damage from spinal cord exposure in fetal sheep," Journal of Pediatric Surgery, vol. 30, no. 7, pp. 1028-1033, 1995.

[196] D. S. Heffez, J. Aryanpur, G. M. Hutchins, and J. M. Freeman, "The paralysis associated with myelomeningocele: clinical and experimental data implicating a preventable spinal cord injury," Neurosurgery, vol. 26, no. 6, pp. 987-992, 1990.

[197] D. S. Heffez, J. Aryanpur, N. A. C. Rotellini et al., "Intrauterine repair of experimental surgically created dysraphism," Neurosurgery, vol. 32, no. 6, pp. 1005-1010, 1993.

[198] M. Meuli, C. Meuli-Simmen, G. M. Hutchins et al., "In utero surgery rescues neurological function at birth in sheep with spina bifida," Nature Medicine, vol. 1, no. 4, pp. 342-347, 1995.

[199] N. Tulipan, J. P. Bruner, M. Hernanz-Schulman et al., "Effect of intrauterine myelomeningocele repair on central nervous system structure and function," Pediatric Neurosurgery, vol. 31, no. 4, pp. 183-188, 1999.

[200] Y. Yi, M. Lindemann, A. Colligs, and C. Snowball, "Economic burden of neural tube defects and impact of prevention with folic acid: a literature review," European Journal of Pediatrics, vol. 170, no. 11, pp. 1391-1400, 2011.

[201] S. Chatkupt, F. A. Hol, Y. Y. Shugart et al., "Absence of linkage between familial neural tube defects and PAX3 gene," Journal of Medical Genetics, vol. 32, no. 3, pp. 200-204, 1995.

[202] S. Hanaei, F. Nejat, A. Mortazavi, Z. Habibi, A. Esmaeili, and M. El Khashab, "Identical twins with lumbosacral lipomyelomeningocele," Journal of neurosurgery. Pediatrics, vol. 15, no. 1, pp. 92-95, 2015.

[203] M. R. Amorim, M. A. C. Lima, E. E. Castilla, and I. M. Orioli, "Non-Latin European descent could be a requirement for association of NTDs and MTHFR variant $677 \mathrm{C}>\mathrm{T}$ : a metaanalysis," American Journal of Medical Genetics Part A, vol. 143, no. 15, pp. 1726-1732, 2007.

[204] T. Zhang, J. Lou, R. Zhong et al., "Genetic variants in the folate pathway and the risk of neural tube defects: a meta-analysis of the published literature," PLoS ONE, vol. 8, no. 4, Article ID e59570, 2013.

[205] H. J. Blom, G. M. Shaw, M. Den Heijer, and R. H. Finnell, "Neural tube defects and folate: case far from closed," Nature Reviews Neuroscience, vol. 7, no. 9, pp. 724-731, 2006.

[206] N. Safra, A. G. Bassuk, P. J. Ferguson et al., "Genome-wide association mapping in dogs enables identification of the homeobox gene, NKX2-8, as a genetic component of neural tube defects in humans," PLoS Genetics, vol. 9, no. 7, Article ID e1003646, 2013.

[207] A. G. Bassuk, L. B. Muthuswamy, R. Boland et al., "Copy number variation analysis implicates the cell polarity gene glypican 5 as a human spina bifida candidate gene," Human Molecular Genetics, vol. 22, no. 6, pp. 1097-1111, 2013.

[208] Y. Gao, X. Chen, S. Shangguan et al., "Association study of PARD3 gene polymorphisms with neural tube defects in a Chinese han population," Reproductive Sciences, vol. 19, no. 7, pp. 764-771, 2012.

[209] L. Gonzalez-Herrera, R. Martín Cerda-Flores, M. Luna-Rivero et al., "Paraoxonase 1 polymorphisms and haplotypes and the risk for having offspring affected with spina bifida in Southeast Mexico," Birth Defects Research A-Clinical and Molecular Teratology, vol. 88, no. 11, pp. 987-994, 2010.

[210] J. Liu, L. Wang, Y. Fu et al., "Association between maternal COMT gene polymorphisms and fetal neural tube defects risk in a Chinese population," Birth Defects Research A-Clinical and Molecular Teratology, vol. 100, no. 1, pp. 22-29, 2014.

[211] A. Narisawa, S. Komatsuzaki, A. Kikuchi et al., "Mutations in genes encoding the glycine cleavage system predispose to neural tube defects in mice and humans," Human Molecular Genetics, vol. 21, no. 7, pp. 1496-1503, 2012.

[212] D. R. Krupp, K. L. Soldano, M. E. Garrett, H. Cope, A. E. AshleyKoch, and S. G. Gregory, "Missing genetic risk in neural tube defects: can exome sequencing yield an insight?" Birth Defects Research A-Clinical and Molecular Teratology, vol. 100, no. 8, pp. 642-646, 2014.

[213] S. F. Gilbert, Developmental Biology, Sinauer Associates, Baltimore, Md, USA, 2003.

[214] R. Keller, "Cell migration during gastrulation," Current Opinion in Cell Biology, vol. 17, no. 5, pp. 533-541, 2005.

[215] A. J. Copp, N. D. E. Greene, and J. N. Murdoch, "The genetic basis of mammalian neurulation," Nature Reviews Genetics, vol. 4, no. 10, pp. 784-793, 2003.

[216] A. J. Copp, F. A. Brook, J. Peter Estibeiro, A. S. W. Shum, and D. L. Cockroft, "The embryonic development of mammalian neural tube defects," Progress in Neurobiology, vol. 35, no. 5, pp. 363-403, 1990.

[217] J. A. Golden and G. F. Chernoff, "Intermittent pattern of neural tube closure in two strains of mice," Teratology, vol. 47, no. 1, pp. 73-80, 1993.

[218] M. I. Van Allen, D. K. Kalousek, G. F. Chernoff et al., "Evidence for multi-site closure of the neural tube in humans," American Journal of Medical Genetics, vol. 47, no. 5, pp. 723-743, 1993.

[219] R. O'Rahilly and F. Müller, "The two sites of fusion of the neural folds and the two neuropores in the human embryo," Teratology, vol. 65, no. 4, pp. 162-170, 2002.

[220] A. J. Copp and M. Bernfield, "Etiology and pathogenesis of human neural tube defects: insights from mouse models," Current Opinion in Pediatrics, vol. 6, no. 6, pp. 624-631, 1994.

[221] L. A. Davidson and R. E. Keller, "Neural tube closure in Xenopus laevis involves medial migration, directed protrusive activity, cell intercalation and convergent extension," Development, vol. 126, no. 20, pp. 4547-4556, 1999.

[222] H. W. M. Van Straaten, T. Jaskoll, A. M. J. Rousseau et al., "Raphe of the posterior neural tube in the chick embryo: its closure and reopening as studied in living embryos with a high definition light microscope," Developmental Dynamics, vol. 198, no. 1, pp. 65-76, 1993. 
[223] J.-F. Colas and G. C. Schoenwolf, "Subtractive hybridization identifies chick-cripto, a novel EGF-CFC ortholog expressed during gastrulation, neurulation and early cardiogenesis," Gene, vol. 255, no. 2, pp. 205-217, 2000.

[224] A. J. Copp and N. D. E. Greene, "Defining a PARticular pathway of neural tube closure," Developmental Cell, vol. 18, no. 1, pp. 1-2, 2010.

[225] P. Ybot-Gonzalez, D. Savery, D. Gerrelli et al., "Convergent extension, planar-cell-polarity signalling and initiation of mouse neural tube closure," Development, vol. 134, no. 4, pp. 789-799, 2007.

[226] J.-F. Colas and G. C. Schoenwolf, "Towards a cellular and molecular understanding of neurulation," Developmental Dynamics, vol. 221, no. 2, pp. 117-145, 2001.

[227] J. B. Wallingford, S. E. Fraser, and R. M. Harland, "Convergent extension: the molecular control of polarized cell movement during embryonic development," Developmental Cell, vol. 2, no. 6, pp. 695-706, 2002.

[228] Y. Yamaguchi, N. Shinotsuka, K. Nonomura et al., "Live imaging of apoptosis in a novel transgenic mouse highlights its role in neural tube closure," Journal of Cell Biology, vol. 195, no. 6, pp. 1047-1060, 2011.

[229] I. E. Zohn, C. R. Chesnutt, and L. Niswander, "Cell polarity pathways converge and extend to regulate neural tube closure," Trends in Cell Biology, vol. 13, no. 9, pp. 451-454, 2003.

[230] Y. Komiya and R. Habas, "Wnt signal transduction pathways," Organogenesis, vol. 4, no. 2, pp. 68-75, 2008.

[231] J. L. Smith and G. C. Schoenwolf, "Further evidence of extrinsic forces in bending of the neural plate," Journal of Comparative Neurology, vol. 307, no. 2, pp. 225-236, 1991.

[232] A. S. W. Shum and A. J. Copp, "Regional differences in morphogenesis of the neuroepithelium suggest multiple mechanisms of spinal neurulation in the mouse," Anatomy and Embryology, vol. 194, no. 1, pp. 65-73, 1996.

[233] D. Moran and R. W. Rice, "An ultrastructural examination of the role of cell membrane surface coat material during neurulation," Journal of Cell Biology, vol. 64, no. 1, pp. 172-181, 1975.

[234] R. E. Waterman, "SEM observations of surface alterations associated with neural tube closure in the mouse and hamster," Anatomical Record, vol. 183, no. 1, pp. 95-98, 1975.

[235] R. E. Waterman, "Topographical changes along the neural fold associated with neurulation in the hamster and mouse," American Journal of Anatomy, vol. 146, no. 2, pp. 151-171, 1976.

[236] R. W. Rice and D. J. Moran, "A scanning electron microscopic and x-ray microanalytic study of cell surface material during amphibian neurulation," Journal of Experimental Zoology, vol. 201, no. 3, pp. 471-478, 1977.

[237] L. L. Mak, "Ultrastructural studies of amphibian neural fold fusion," Developmental Biology, vol. 65, no. 2, pp. 435-446, 1978.

[238] T. W. Sadler, "Distribution of surface coat material on fusing neural folds of mouse embryos during neurulation," Anatomical Record, vol. 191, no. 3, pp. 345-349, 1978.

[239] J. A. G. Geelen and J. Langman, "Ultrastructural observations on closure of the neural tube in the mouse," Anatomy and Embryology, vol. 156, no. 1, pp. 73-88, 1979.

[240] A. Smits-Van Prooije, R. Poelmann, J. Dubbeldam, M. Mentink, and C. Vermeij-Keers, "The formation of the neural tube in rat embryos, cultured in vitro, studied with teratogens," Acta Histochemica. Supplement, vol. 32, pp. 41-45, 1986.

[241] H. Takahashi and R. I. Howes, "Binding pattern of ferritinlabeled lectins (RCAI and WGA) during neural tube closure in the bantam embryo," Anatomy and Embryology, vol. 174, no. 3, pp. 283-288, 1986.

[242] H. Takahashi, "Changes in peanut lectin binding sites on the neuroectoderm during neural tube formation in the bantam chick embryo," Anatomy and Embryology, vol. 178, no. 4, pp. 353-358, 1988.

[243] J. Holmberg, D. L. Clarke, and J. Frisen, "Regulation of repulsion versus adhesion by different splice forms of an Eph receptor," Nature, vol. 408, no. 6809, pp. 203-206, 2000.

[244] N. M. Abdul-Aziz, M. Turmaine, N. D. E. Greene, and A. J. Copp, "EphrinA-EphA receptor interactions in mouse spinal neurulation: implications for neural fold fusion," The International Journal of Developmental Biology, vol. 53, no. 4, pp. 559568, 2009.

[245] C. Pyrgaki, P. Trainor, A.-K. Hadjantonakis, and L. Niswander, "Dynamic imaging of mammalian neural tube closure," Developmental Biology, vol. 344, no. 2, pp. 941-947, 2010.

[246] M. J. Harris and D. M. Juriloff, "Mini-review: toward understanding mechanisms of genetic neural tube defects in mice," Teratology, vol. 60, no. 5, pp. 292-305, 1999.

[247] A. Dady, E. Havis, V. Escriou, M. Catala, and J.-L. Duband, "Junctional neurulation: a unique developmental program shaping a discrete region of the spinal cord highly susceptible to neural tube defects," Journal of Neuroscience, vol. 34, no. 39, pp. 13208-13221, 2014.

[248] L. S. Segal, W. Czoch, W. L. Hennrikus, M. Wade Shrader, and P. M. Kanev, "The spectrum of musculoskeletal problems in lipomyelomeningocele," Journal of Children's Orthopaedics, vol. 7, no. 6, pp. 513-519, 2013.

[249] M. Montcouquiol, E. B. Crenshaw III, and M. W. Kelley, "Noncanonical Wnt signaling and neural polarity," Annual Review of Neuroscience, vol. 29, pp. 363-386, 2006.

[250] J. B. Wallingford and R. Habas, "The developmental biology of Dishevelled: an enigmatic protein governing cell fate and cell polarity," Development, vol. 132, no. 20, pp. 4421-4436, 2005.

[251] P. Ybot-Gonzalez, C. Gaston-Massuet, G. Girdler et al., "Neural plate morhogenesis during mouse neurulation is regulated by antagonism of Bmp signalling," Development, vol. 134, no. 17, pp. 3203-3211, 2007.

[252] Y. Yamaguchi and M. Miura, "How to form and close the brain: insight into the mechanism of cranial neural tube closure in mammals," Cellular and Molecular Life Sciences, vol. 70, no. 17, pp. 3171-3186, 2013.

[253] S. L. McDonald and A. Silver, "The opposing roles of Wnt-5a in cancer," British Journal of Cancer, vol. 101, no. 2, pp. 209-214, 2009.

[254] R. Keller, "Shaping the vertebrate body plan by polarized embryonic cell movements," Science, vol. 298, no. 5600, pp. 1950-1954, 2002.

[255] A. Dabdoub, M. J. Donohue, A. Brennan et al., "Wnt signaling mediates reorientation of outer hair cell stereociliary bundles in the mammalian cochlea," Development, vol. 130, no. 11, pp. 2375-2384, 2003.

[256] L. V. Goodrich and D. Strutt, "Principles of planar polarity in animal development," Development, vol. 138, no. 10, pp. 18771892, 2011.

[257] J. Shih and R. Keller, "Cell motility driving mediolateral intercalation in explants of Xenopus laevis," Development, vol. 116, no. 4, pp. 901-914, 1992.

[258] L. A. Lowery and H. Sive, "Strategies of vertebrate neurulation and a re-evaluation of teleost neural tube formation," Mechanisms of Development, vol. 121, no. 10, pp. 1189-1197, 2004. 
[259] M. J. Harrington, E. Hong, and R. Brewster, "Comparative analysis of neurulation: first impressions do not count," Molecular Reproduction and Development, vol. 76, no. 10, pp. 954-965, 2009.

[260] T. J. Klein and M. Mlodzik, "Planar cell polarization: an emerging model points in the right direction," Annual Review of Cell and Developmental Biology, vol. 21, pp. 155-176, 2005.

[261] H. Matakatsu and S. S. Blair, "Interactions between Fat and Dachsous and the regulation of planar cell polarity in the Drosophila wing," Development, vol. 131, no. 15, pp. 3785-3794, 2004.

[262] J. Casal, P. A. Lawrence, and G. Struhl, "Two separate molecular systems, Dachsous/Fat and Starry night/Frizzled, act independently to confer planar cell polarity," Development, vol. 133, no. 22, pp. 4561-4572, 2006.

[263] E. K. Vladar, D. Antic, and J. D. Axelrod, "Planar cell polarity signaling: the developing cell's compass," Cold Spring Harbor Perspectives in Biology, vol. 1, no. 3, Article ID a002964, 2009.

[264] M. Matis and J. D. Axelrod, "Regulation of PCP by the fat signaling pathway," Genes and Development, vol. 27, no. 20, pp. 2207-2220, 2013.

[265] D. Gubb and A. García-Bellido, "A genetic analysis of the determination of cuticular polarity during development in Drosophila melanogaster," Journal of Embryology and Experimental Morphology, vol. 68, pp. 37-57, 1982.

[266] P. N. Adler, J. Taylor, and J. Charlton, "The domineering nonautonomy of frizzled and Van Gogh clones in the Drosophila wing is a consequence of a disruption in local signaling," Mechanisms of Development, vol. 96, no. 2, pp. 197-207, 2000.

[267] L. L. Wong and P. N. Adler, "Tissue polarity genes of Drosophila regulate the subcellular location for prehair initiation in pupal wing cells," Journal of Cell Biology, vol. 123, no. 1, pp. 209-221, 1993.

[268] J. N. Murdoch, K. Doudney, C. Paternotte, A. J. Copp, and P. Stanier, "Severe neural tube defects in the loop-tail mouse result from mutation of Lppl, a novel gene involved in floor plate specification," Human Molecular Genetics, vol. 10, no. 22, pp. 2593-2601, 2001.

[269] J. Wang, N. S. Hamblet, S. Mark et al., "Dishevelled genes mediate a conserved mammalian PCP pathway to regulate convergent extension during neurulation," Development, vol. 133, no. 9, pp. 1767-1778, 2006.

[270] J. A. Curtin, E. Quint, V. Tsipouri et al., "Mutation of Celsr1 disrupts planar polarity of inner ear hair cells and causes severe neural tube defects in the mouse," Current Biology, vol. 13, no. 13, pp. 1129-1133, 2003.

[271] N. S. Hamblet, N. Lijam, P. Ruiz-Lozano et al., "Dishevelled 2 is essential for cardiac outflow tract development, somite segmentation and neural tube closure," Development, vol. 129, no. 24, pp. 5827-5838, 2002.

[272] S. L. Etheridge, S. Ray, S. Li et al., "Murine dishevelled 3 functions in redundant pathways with dishevelled 1 and 2 in normal cardiac outflow tract, cochlea, and neural tube development," PLoS Genetics, vol. 4, no. 11, Article ID e1000259, 2008.

[273] Y. Wang, N. Guo, and J. Nathans, "The role of Frizzled3 and Frizzled6 in neural tube closure and in the planar polarity of inner-ear sensory hair cells," Journal of Neuroscience, vol. 26, no. 8, pp. 2147-2156, 2006.

[274] E. Torban, A.-M. Patenaude, S. Leclerc et al., "Genetic interaction between members of the Vangl family causes neural tube defects in mice," Proceedings of the National Academy of Sciences of the United States of America, vol. 105, no. 9, pp. 3449-3454, 2008.

[275] X. Lu, A. G. M. Borchers, C. Jolicoeur, H. Rayburn, J. C. Baker, and M. Tessier-Lavigne, "PTK7/CCK-4 is a novel regulator of planar cell polarity in vertebrates," Nature, vol. 430, no. 6995, pp. 93-98, 2004.

[276] J. N. Murdoch, D. J. Henderson, K. Doudney et al., "Disruption of scribble (Scrb1) causes severe neural tube defects in the circletail mouse," Human Molecular Genetics, vol. 12, no. 2, pp. 87-98, 2003.

[277] R. Suriben, S. Kivimäe, D. A. C. Fisher, R. T. Moon, and B. N. R. Cheyette, "Posterior malformations in Dact1 mutant mice arise through misregulated Vangl2 at the primitive streak," Nature Genetics, vol. 41, no. 9, pp. 977-985, 2009.

[278] M. Placzek, T. Yamada, M. Tessier-Lavigne, T. Jessell, and J. Dodd, "Control of dorsoventral pattern in vertebrate neural development: induction and polarizing properties of the floor plate," Development, vol. 113, no. 2, pp. 105-122, 1991.

[279] M. Placzek, M. Tessier-Lavigne, T. Yamada, T. Jessell, and J. Dodd, "Mesodermal control of neural cell identity: floor plate induction by the notochord," Science, vol. 250, no. 4983, pp. 985-988, 1990.

[280] T. Yamada, M. Placzek, H. Tanaka, J. Dodd, and T. M. Jessell, "Control of cell pattern in the developing nervous system: polarizing activity of the floor plate and notochord," Cell, vol. 64, no. 3, pp. 635-647, 1991.

[281] T. Yamada, S. L. Pfaff, T. Edlund, and T. M. Jessell, "Control of cell pattern in the neural tube: motor neuron induction by diffusible factors from notochord and floor plate," Cell, vol. 73, no. 4, pp. 673-686, 1993.

[282] M. D. Goulding, A. Lumsden, and P. Gruss, "Signals from the notochord and floor plate regulate the region-specific expression of two Pax genes in the developing spinal cord," Development, vol. 117, no. 3, pp. 1001-1016, 1993.

[283] D. S. Eom, S. Amarnath, J. L. Fogel, and S. Agarwala, "Bone morphogenetic proteins regulate hinge point formation during neural tube closure by dynamic modulation of apicobasal polarity," Birth Defects Research Part A: Clinical and Molecular Teratology, vol. 94, no. 10, pp. 804-816, 2012.

[284] H. W. M. van Straaten, J. W. M. Hekking, E. J. L. M. WiertzHoessels, F. Thors, and J. Drukker, "Effect of the notochord on the differentiation of a floor plate area in the neural tube of the chick embryo," Anatomy and Embryology, vol. 177, no. 4, pp. 317324, 1988.

[285] H. W. M. van Straaten, J. W. M. Hekking, F. Thors, E. L. WiertzHoessels, and J. Drukker, "Induction of an additional floor plate in the neural tube," Acta Morphologica Neerlando-Scandinavica, vol. 23, no. 2, pp. 91-97, 1985.

[286] J. L. Smith and G. C. Schoenwolf, "Notochordal induction of cell wedging in the chick neural plate and its role in neural tube formation," Journal of Experimental Zoology, vol. 250, no. 1, pp. 49-62, 1989.

[287] P. Ybot-Gonzalez, P. Cogram, D. Gerrelli, and A. J. Copp, "Sonic hedgehog and the molecular regulation of mouse neural tube closure," Development, vol. 129, no. 10, pp. 2507-2517, 2002.

[288] K. F. Liem Jr., T. M. Jessell, and J. Briscoe, "Regulation of the neural patterning activity of sonic hedgehog by secreted BMP inhibitors expressed by notochord and somites," Development, vol. 127, no. 22, pp. 4855-4866, 2000. 
[289] N. D. E. Greene and A. J. Copp, "Development of the vertebrate central nervous system: formation of the neural tube," Prenatal Diagnosis, vol. 29, no. 4, pp. 303-311, 2009.

[290] S. G. McShane, M. A. Molè, D. Savery, N. D. E. Greene, P. P. L. Tam, and A. J. Copp, "Cellular basis of neuroepithelial bending during mouse spinal neural tube closure," Developmental Biology, vol. 404, no. 2, pp. 113-124, 2015.

[291] P. Ybot-Gonzalez, C. Gaston-Massuet, G. Girdler et al., "Neural plate morphogenesis during mouse neurulation is regulated by antagonism of Bmp signalling," Development, vol. 134, no. 17, pp. 3203-3211, 2007.

[292] J. A. McMahon, S. Takada, L. B. Zimmerman, C.-M. Fan, R. M. Harland, and A. P. McMahon, "Noggin-mediated antagonism of BMP signaling is required for growth and patterning of the neural tube and somite," Genes \& Development, vol. 12, no. 10, pp. 1438-1452, 1998.

[293] R. W. Stottmann, M. Berrong, K. Matta, M. Choi, and J. Klingensmith, "The BMP antagonist Noggin promotes cranial and spinal neurulation by distinct mechanisms," Developmental Biology, vol. 295, no. 2, pp. 647-663, 2006.

[294] J. Groppe, J. Greenwald, E. Wiater et al., "Structural basis of BMP signalling inhibition by the cystine knot protein Noggin," Nature, vol. 420, no. 6916, pp. 636-642, 2002.

[295] L. J. Brunet, J. A. McMahon, A. P. McMahon, and R. M. Harland, "Noggin, cartilage morphogenesis, and joint formation in the mammalian skeleton," Science, vol. 280, no. 5368, pp. 1455-1457, 1998.

[296] J. Laurikkala, Y. Kassai, L. Pakkasjärvi, I. Thesleff, and N. Itoh, "Identification of a secreted BMP antagonist, ectodin, integrating BMP, FGF, and SHH signals from the tooth enamel knot," Developmental Biology, vol. 264, no. 1, pp. 91-105, 2003.

[297] G. W. Yip, P. Ferretti, and A. J. Copp, "Heparan sulphate proteoglycans and spinal neurulation in the mouse embryo," Development, vol. 129, no. 9, pp. 2109-2119, 2002.

[298] B. Ciruna and J. Rossant, "FGF signaling regulates mesoderm cell fate specification and morphogenetic movement at the primitive streak," Developmental Cell, vol. 1, no. 1, pp. 37-49, 2001.

[299] S. Takada, K. L. Stark, M. J. Shea, G. Vassileva, J. A. McMahon, and A. P. McMahon, "Wnt-3a regulates somite and tailbud formation in the mouse embryo," Genes and Development, vol. 8, no. 2, pp. 174-189, 1994.

[300] K. Niederreither, V. Subbarayan, P. Dollé, and P. Chambon, "Embryonic retinoic acid synthesis is essential for early mouse post-implantation development," Nature Genetics, vol. 21, no. 4, pp. 444-448, 1999.

[301] C. F. Hung, H. K. Hsu, and K. R. Lin, "SEM observations of the neural fold associated with neurulation in the rat," Proceedings of the National Science Council, Republic of China, Part B: Life Sciences, vol. 10, no. 4, pp. 287-290, 1986.

[302] A. Lawson and M. A. England, "Neural fold fusion in the cranial region of the chick embryo," Developmental Dynamics, vol. 212, no. 4, pp. 473-481, 1998.

[303] H. W. M. Van Straaten, M. C. E. Peeters, K. F. W. Szpak, and J. W. M. Hekking, "Initial closure of the mesencephalic neural groove in the chick embryo involves a releasing zipping-up mechanism," Developmental Dynamics, vol. 209, no. 4, pp. 333341, 1997.

[304] B. Ciruna, A. Jenny, D. Lee, M. Mlodzik, and A. F. Schier, "Planar cell polarity signalling couples cell division and morphogenesis during neurulation," Nature, vol. 439, no. 7073, pp. 220-224, 2006.
[305] D. Rashid, K. Newell, L. Shama, and R. Bradley, "A requirement for NF-protocadherin and TAF1/Set in cell adhesion and neural tube formation," Developmental Biology, vol. 291, no. 1, pp. 170181, 2006.

[306] L. A. Davidson, A. M. Ezin, and R. Keller, "Embryonic wound healing by apical contraction and ingression in Xenopus laevis," Cell Motility and the Cytoskeleton, vol. 53, no. 3, pp. 163-176, 2002.

[307] M. R. Brouns, S. F. Matheson, K.-Q. Hu et al., "The adhesion signaling molecule p190 RhoGAP is required for morphogenetic processes in neural development," Development, vol. 127, no. 22, pp. 4891-4903, 2000.

[308] I. de Diego, K. Kyriakopoulou, D. Karagogeos, and M. Wassef, "Multiple influences on the migration of precerebellar neurons in the caudal medulla," Development, vol. 129, no. 2, pp. 297-306, 2002.

[309] R. Keller, "Mechanisms of elongation in embryogenesis," Development, vol. 133, no. 12, pp. 2291-2302, 2006.

[310] D. A. Hackett, J. L. Smith, and G. C. Schoenwolf, "Epidermal ectoderm is required for full elevation and for convergence during bending of the avian neural plate," Developmental Dynamics, vol. 210, no. 4, pp. 397-406, 1997.

[311] S. L. Haigo, J. D. Hildebrand, R. M. Harland, and J. B. Wallingford, "Shroom induces apical constriction and is required for hingepoint formation during neural tube closure," Current Biology, vol. 13, no. 24, pp. 2125-2137, 2003.

[312] M. Bailly, "Connecting cell adhesion to the actin polymerization machinery: vinculin as the missing link?" Trends in Cell Biology, vol. 13, no. 4, pp. 163-165, 2003.

[313] E. Andersson, L. Bryjova, K. Biris, T. P. Yamaguchi, E. Arenas, and V. Bryja, "Genetic interaction between Lrp6 and Wnt5a during mouse development," Developmental Dynamics, vol. 239, no. 1, pp. 237-245, 2010.

[314] X. Miró, X. Zhou, S. Boretius et al., "Haploinsufficiency of the murine polycomb gene Suz12 results in diverse malformations of the brain and neural tube," Disease Models and Mechanisms, vol. 2, no. 7-8, pp. 412-418, 2009.

[315] P. Magnaghi, C. Roberts, S. Lorain, M. Lipinski, and P. J. Scambler, "HIRA, a mammalian homologue of saccharomyces cerevisiae transcriptional co-repressors, interacts with Pax3," Nature Genetics, vol. 20, no. 1, pp. 74-77, 1998.

[316] M. K. Pirity, W.-L. Wang, L. V. Wolf, E. R. Tamm, N. SchreiberAgus, and A. Cvekl, "Rybp, a polycomb complex-associated protein, is required for mouse eye development," BMC Developmental Biology, vol. 7, article 39, 2007.

[317] K. Fujii, "Primary cilia and hedgehog signaling," No To Hattatsu, vol. 47, pp. 259-265, 2015.

[318] C. Goumy, M. Gay-Bellile, E. Eymard-Pierre et al., "De novo 2q36.1q36.3 interstitial deletion involving the PAX3 and EPHA4 genes in a fetus with spina bifida and cleft palate," Birth Defects Research Part A: Clinical and Molecular Teratology, vol. 100, no. 6, pp. 507-511, 2014.

[319] F. R. Schubert, P. Tremblay, A. Mansouri et al., "Early mesodermal phenotypes in Splotch suggest a role for Pax3 in the formation of epithelial somites," Developmental Dynamics, vol. 222, no. 3, pp. 506-521, 2001.

[320] H. Roudgari, P. A. Farndon, A. D. Murray, C. Hardy, and Z. Miedzybrodzka, "Is PATCHED an important candidate gene for neural tube defects? Cranial and thoracic neural tube defects in a family with Gorlin syndrome: a case report," Clinical Genetics, vol. 82, no. 1, pp. 71-76, 2012. 
[321] J. Luo, N. Balkin, J. F. Stewart, J. F. Sarwark, J. Charrow, and J. S. Nye, "Neural tube defects and the $13 \mathrm{q}$ deletion syndrome: evidence for a critical region in 13q33-34," American Journal of Medical Genetics Part A, vol. 91, no. 3, pp. 227-230, 2000.

[322] L. Rodríguez, I. C. Pérez, J. H. Montes, M. L. L. Jareño, F. L. Grondona, and M. L. Martínez-Frías, "Terminal deletion of the chromosome 7(q36-qter) in an infant with sacral agenesis and anterior myelomeningocele," American Journal of Medical Genetics, vol. 110, no. 1, pp. 73-77, 2002. 

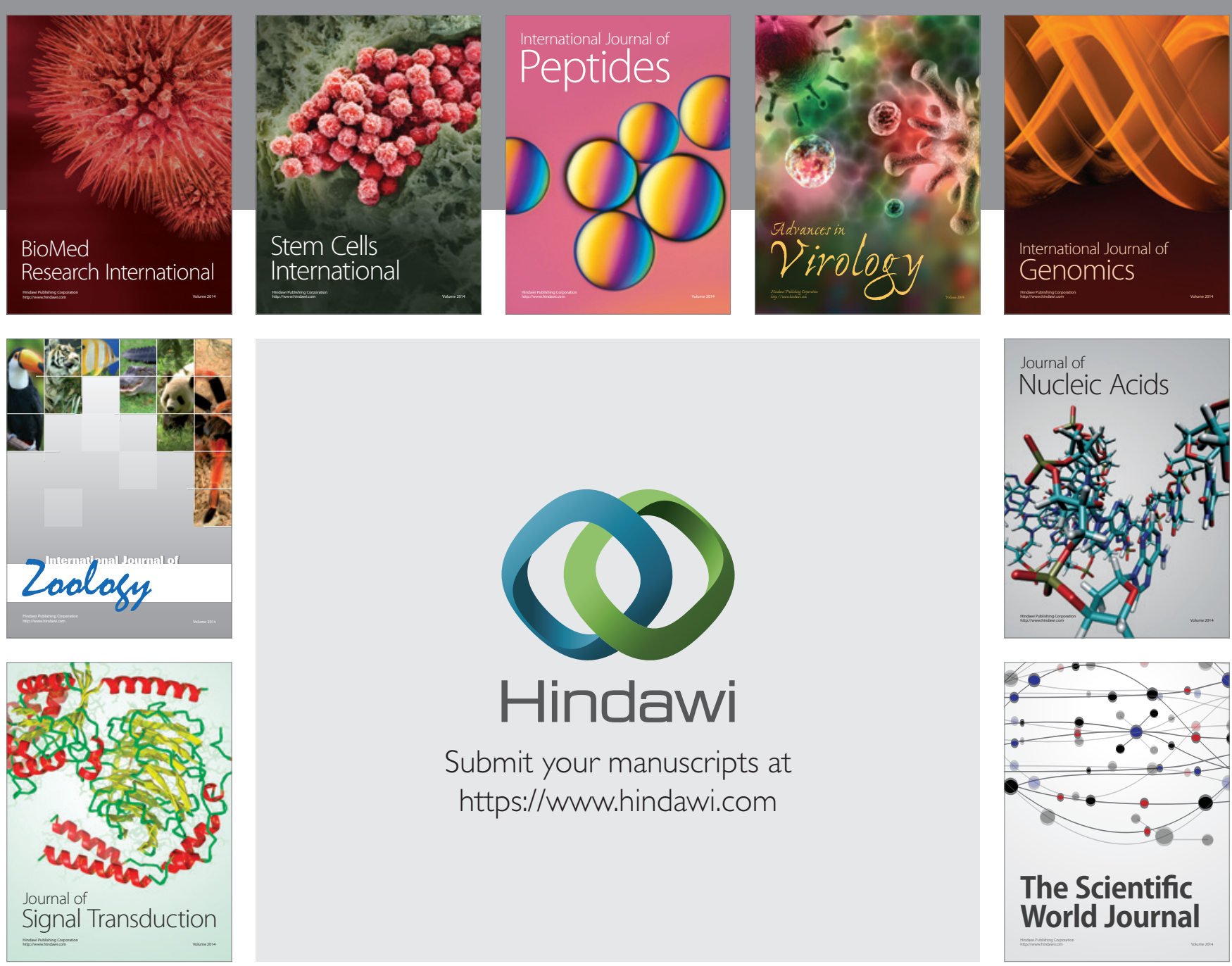

Submit your manuscripts at

https://www.hindawi.com
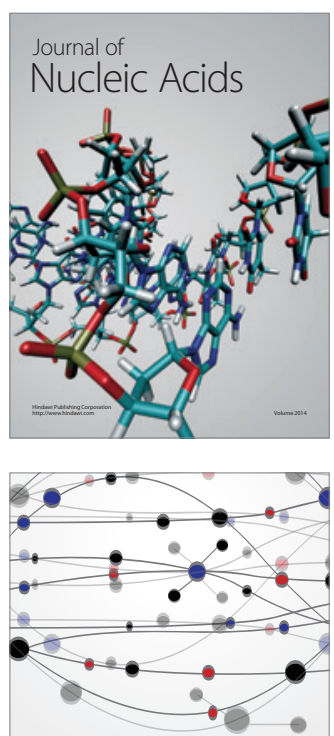

The Scientific World Journal
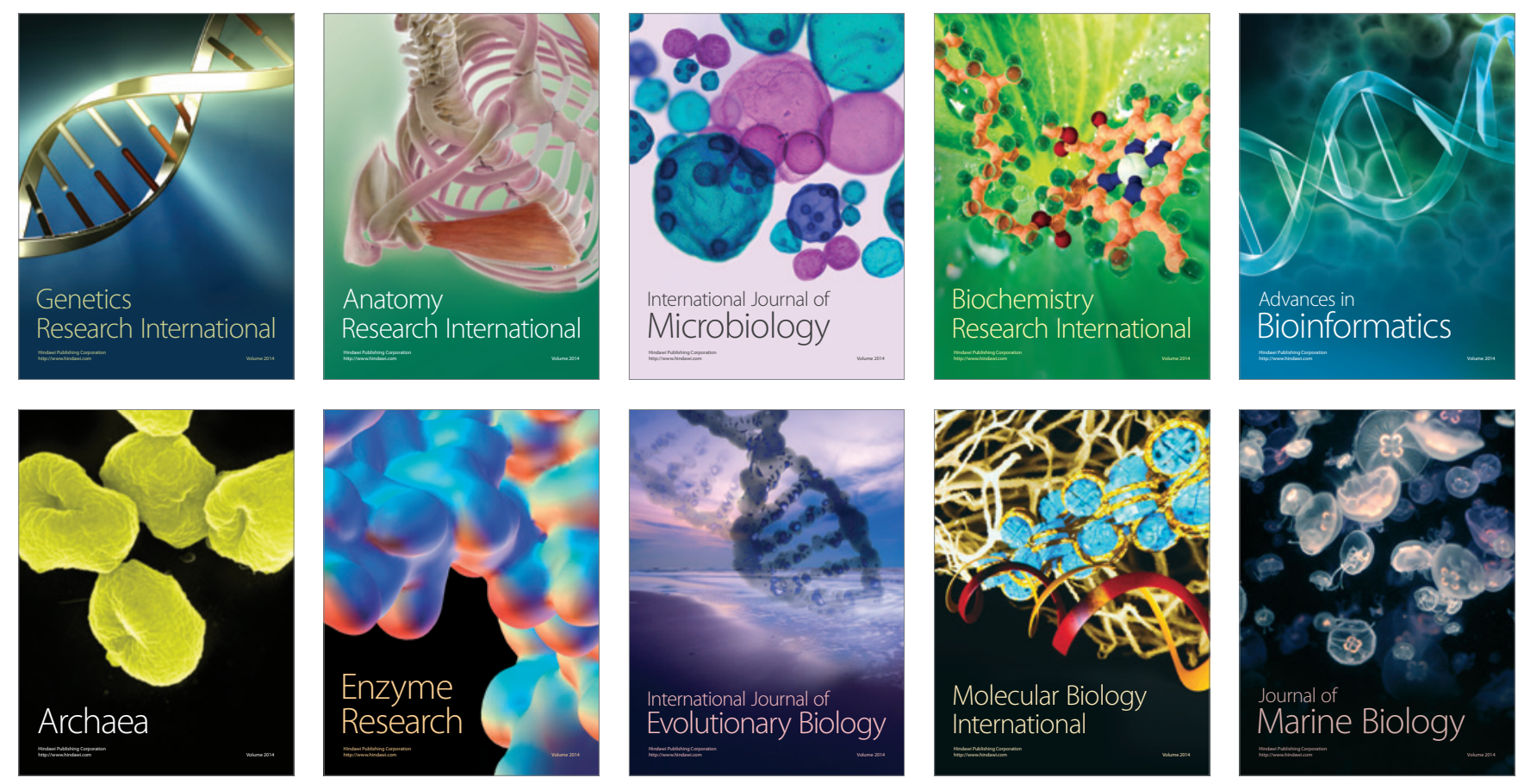